IMMIGRANTS AND HOUSING IN CANADA'S SECOND-TIER CITIES

\author{
by \\ Melissa Gasic \\ Bachelor of Architecture, Belgrade University, 2009 \\ A Major Research Paper \\ Presented to Ryerson University \\ in partial fulfillment of the requirements for the degree of \\ Master of Planning \\ in \\ Urban Development \\ Toronto, Ontario, Canada 2013
}

CCMelissa Gasic 2013 


\section{Author's Declaration}

I hereby declare that I am the sole author of this major research paper. This is a true copy of the major research paper, including any final revisions as accepted by my examiners.

I authorize Ryerson University to lend this major research paper to other institutions of individuals for the purpose of scholarly research.

I further authorize Ryerson University to reproduce this major research paper by photocopying or by other means, in total or in part, at the request of other institutions of individuals for the purpose of scholarly research.

I understand that my major research paper may be made electronically available to the public. 


\title{
IMMIGRANTS AND HOUSING IN CANADA'S SECOND-TIER CITIES
}

\author{
(C)Melissa Gasic, 2013 \\ Master of Planning \\ In \\ Urban Development \\ Ryerson University
}

\begin{abstract}
In order to affect a more even distribution of immigrants across the country the federal government started a dispersion initiative. The aim of the diversion initiative was to increase the number of immigrants settling in smaller, second- and third-tier cities since the majority of immigrants settle in the three major metropolises of Toronto, Montreal, and Vancouver. Given the fact that smaller centres depend on immigration for economic and demographic progress, and that accessing housing presents one of the pillars of broader integration into a society, providing for better housing access in smaller centres thus emanates as an issue requiring resolution as a way to attract and retain immigrants.
\end{abstract}

Key words: Immigrants, housing, second-tier cities, Canada 


\section{Table of Contents}

$\begin{array}{ll}\text { I. Introduction } & 1\end{array}$

a) Definition of Terms 2

b) Context 2

c) Problem Statement 4

$\begin{array}{ll}\text { II. Methodology } & 6\end{array}$

$\begin{array}{ll}\text { III. Literature Review } & 8\end{array}$

$\begin{array}{ll}\text { a) Housing Issues } & 8\end{array}$

i) Affordability, Adequacy and Suitability 8

ii) Discrimination $\quad 9$

iii) Spatial patterns and Concentration 11

iv) Homeownership 11

$\begin{array}{ll}\text { v) Refugees } & 13\end{array}$

vi) Social Networks 13

b) Findings in Second-tier cities $\quad 14$

i) Immigration and Housing 14

ii) Refugees 18

iii) Homeownership $\quad 19$

iv) Housing Information 20

$\begin{array}{ll}\text { v) Barriers and Discrimination } & 21\end{array}$

vi) Affordability, Adequacy, and Suitability 24

vii) Income Levels 25

viii) Employment 26

ix) Social Networks $\quad 27$

x) Diminishing Supply of Affordable Units 28

xi) Access to Amenities and Services $\quad 29$

c) Summary of the Literature Review Findings 30

IV. Income, Core Housing Need, Ownership Rate, and Affordability 34

V. Policy Overview $\quad 46$

a) Immigration 46

b) Settlement 50 
c) Housing

i) Housing for Immigrants

VI. Discussion and Conclusion

61

VII. References

69 


\section{$\underline{\text { List of Tables }}$}

Table 1: Household statistics by household immigrant status. Census Metropolitan Areas, 2006

Table 2: Household statistics by household immigrant status ( $<5$ yrs. in Canada). Census

Metropolitan Areas, 2006

Table 3: Rental Market Indicators: Privately Initiated Apartment Structures of Three Units and

Over, Provinces and Major Centres 


\section{Introduction}

Immigration has profoundly shaped Canadian settlement. Patterns and flows of immigration have changed over time from predominantly European farm settlements early on, to modern-day metropolises attracting immigrants from all over the world. In the developed world, Canada ranks second to Australia in the proportion of foreign-born population (18\% compared to 22\%) (Citizenship and Immigration Canada, 2007). With the country’s declining birth rate and aging population, immigrants could, around 2030, become the primary driver of population growth in Canada (Statistics Canada, 2008).

The federal government, starting with the seminal paper “Towards a More Balanced Geographic Distribution of Immigrants” in 2001, has promoted the regionalization of immigration (Citizen and Immigration Canada, 2001). Since the majority of immigrants settle in the three major metropolises of Toronto, Montreal, and Vancouver (Schellenberg, 2004; Shanes, 2006), the aim of this diversion policy was to increase the number of immigrants settling in smaller, second- and third-tier cities.

The immigration flows and the dispersion policy drive raise questions about the effects the new immigrant population has on second-tier cities. While the arrival of immigrants may bolster the community economically, it also generates a range of challenges to which planners need to respond. Housing not only provides protection, privacy and creates the physical realm of our cities, but also encompasses and supports all human activity (Stone, 1993), and is recognized as a human right (Hulchanski, 2005). Provision of housing is thus paramount to immigrants and residents alike. The obstacles that immigrants face in accessing housing reveal social misconceptions, openness or constraints within a particular community, as well as the institutional arrangements that prevail (Chambon, Hulchanski, Murdie, \& Texeira, 1997). Thus, an understanding of the experiences and issues that arise in an attempt to access housing in 
second-tier cities can help policy makers, community members, and planners create more inclusive and just places for newcomers.

\section{a) Definition of Terms}

Statistics Canada (Bernard, 2008) classifies urban centres according to the number of residents: very large cities include the three Census Metropolitan Areas (CMAs) of Montréal, Toronto, and Vancouver; large cities are all other CMAs exceeding 500,000 residents; mid-sized cities are the twenty CMAs with 100,000 to 500,000 residents; small centres have 15,000 to 100,000 residents, and beyond that are small towns and rural areas. The focus of this paper will be on mid-sized cities with more than 100,000 residents, from now on referred to as second-tier cities, since immigrant settlement outside the three major metropolises is directed towards these cities rather than small centres and rural areas (Chui, Tran, \& Maheux, 2007; Wachsmuth, 2008).

Immigrants, according to Kilbride and Webber’s (2006) definition, which is adopted for the purposes of this paper, are those who have been in Canada for fewer than 10 years and include individuals without status, refugee claimants, convention refugees, permanent residents and Canadian citizens who arrived as either independent or family class immigrants.

\section{b) Context}

The policy direction on immigration is largely the prerogative of the federal government. It serves to satisfy the needs and requirements of a broader social and economic context while simultaneously enabling conditions under which immigrants can integrate and thrive. The impetus behind the dispersal drive stemmed from concerns that the flow of immigrants into the three largest cities had an adverse demographic, economic and political effect on smaller communities (Derwing \& Krahn, 2008; Abu-Ayyash \& Brochu, 2006; Walton-Roberts, 2004). 
The diversion of immigrant streams presented an opportunity for economic growth of smaller communities and a more balanced population distribution among regions, as well as among smaller and larger provinces (Garcea, 2006; Hyndman, Schuurman, \& Fiedler, 2006). The goal of the dispersal policy was to direct settlement away from the three main destination points of Toronto, Vancouver, and Montreal to other cities and regions across the country.

The federal dispersion policy was initially enabled through the Provincial Nominee Program (PNP), which served to transfer some immigration powers to the provinces. The PNP was introduced in the late 1990s after the federal government signed an agreement with Quebec, essentially transferring immigration to that province’s domain (Carter, Pandey, \& Townsend, 2010). The PNP allowed the provinces and territories to play a more prominent role in immigrant attraction by designating immigrants of their choosing as nominees. The provincial nominees are given a priority in immigration application processing at the federal level. In addition, the program allows for the increase of nominees, according to each province's need, relative to other categories of immigrants. The PNP in Manitoba, for example, as the dominant stream of immigrants into the province, managed to increase the number of new arrivals by $235 \%$ since the program's inception; in 1999, the year after the program was introduced, the number of PNP arrivals comprised $11 \%$ of all immigrants while in 2006 this number reached 66\%-an absolute increase of more than 6,200 new arrivals in 2006 in comparison to 1999 (Carter, Morrish, \& Amoyaw, 2008).

Similarly, the further dispersion of immigrant settlements was facilitated by giving municipalities a greater role in attracting and retaining immigrants. This was initiated in Ontario in 2005 through the Canada Ontario Immigration Agreement (COIA). The agreement provided funding through the Local Immigration Partnership (LIP) initiative, which in turn spurred the interest of municipalities and local stakeholders in developing strategic plans and receptive 
environments for newcomers (Biles, Burstein, \& Frideres, 2008; Bradford \& Andrew, 2010). The goal of this initiative was to provide the governance structure for building the capacity of local institutions to deliver in the areas of immigrant settlement, language services, and labour market assistance, with the main goal of attracting and retaining immigrants in second- and thirdtier cities.

\section{c) Problem Statement}

Given that all levels of government are interested in a more dispersed settlement of immigrants across the country, whereas the majority of them now settle in the three major CMAs of Toronto, Montreal and Vancouver, and given the fact that housing presents a first step in their integration into a new society, this paper will try to answer the following questions: what are the key issues that immigrants are confronted with in their attempt to access housing, what evidence is there that pertains to immigrants' housing trajectories in second-tier cities, and how effectively do existing policies in second-tier cities address these issues?

The question of immigrant settlement is intrinsically tied to the housing process. Finding and accessing housing is usually the first task immigrants face upon arrival. This step helps them not only secure a roof over their head but also establishes permanency on a psychological level (Danso \& Grant, 2001). Accessing housing represents a first step in the integration of immigrants into a new country. The relative ease or difficulty that immigrants encounter in accessing housing subsequently spurs or delays the other aspects of their integration, such as social, economic, employment, etc. (Carter \& Polevychok, 2004; Danso \& Grant, 2000). Immigrants are unfamiliar with local customs and institutions, and as such are disadvantaged in the housing market (Chambon et al., 1997). In addition, they have to overcome the issues of affordability, shortage of supportive housing, and discrimination. According to Murdie et al. (1995, p.11), "the 
outcome of these barriers is fewer choices in the housing market, fewer locational choices within the city, overcrowding, and overpayment for accommodation.” Thus, a successful first step of integration requires accessing housing in a timely manner. The opposite was the case for immigrants in British Columbia, where Mattu (2002) found that it took immigrants an average of three to four years to settle into permanent housing. Similarly, Murdie (2003, p.195) found that Somali immigrants in Toronto had a "regressive housing career", in comparison to their European counterparts, which affected their integration due to the delayed access to adequate housing.

Housing not only fosters immigrants' integration, but is also vitally important for their health and well-being. Housing is one of the social determinants of health, meaning that living conditions, as well as genetics or lifestyle choices, are primary factors influencing human health (Mikkonen \& Raphael, 2010). Research demonstrates that housing, as one of the key living conditions, plays a significant role in health outcomes. This is especially true for children, as research shows that housing deprivation in early childhood has a moderate to severe health impact in adulthood (Bryant, 2003). In addition, it has been demonstrated that socio-economic conditions have more impact on immigrants' health than on non-immigrants (Dunn \& Dyck, 1998). Closely related to health issues is the relationship between good housing and community support networks, which provide for social integration and immigrant well-being. Improved housing conditions for immigrants generally increase their access to both formal and informal support networks, which allow for richer social connections to form (Carter and Polevychok, 2004). 


\section{Methodology}

In the literature on immigrant housing in Canada, the terms mid-sized cities and secondtier cities are used interchangeably, denoting cities larger than 100,000 residents, while always excluding the three largest CMAs. For the purposes of this paper, second-tier cities are defined as all Canadian cities exceeding 100,000 residents, and excluding Toronto, Montréal, and Vancouver.

The answer to the questions posed will be sought by first reviewing the literature in order to identify the key issues that confront immigrants when accessing housing in Canada. Next, the literature on second-tier cities in Canada will be analyzed comprehensively to understand and document the key immigrant housing issues identified in the first step. These facts will then be compared to the overall findings on issues of immigrant housing to assess how second-tier cities fare in relation to these issues.

Next, this research will utilize the CMHC 2006 \& 2001 Census Housing Series Issue 7, and Community Profiles from Statistics Canada in order to extract the housing data for immigrants in second-tier cities, such as income, core housing need, ownership rate, and affordability, and compare them to the metropolitan CMAs of Toronto, Vancouver, and Montréal. Tabulations and calculations will be performed in order to draw comparisons between them and to assess changes over time. In addition, the CMHC Rental Market Reports for secondtier cities will be reviewed in order to determine the availability of rental housing. The purpose of this step is to both augment the literature findings of the previous step and provide information on the key issues for which there is no literature data on second-tier cities.

Lastly, policies and programs pertaining to housing and immigrant dispersal, across all levels of government, will be examined by reviewing the literature and government documents to 
determine the extent to which these policies and programs address the key housing issues in second-tier cities.

The findings from the four-step methodology will shed more light on the relevant housing issues and existing housing policies in second-tier cities, with the ultimate aim of benefiting the integration of immigrants in a new country, and contributing to the discussion on government policies of settlement dispersal—away from the three major CMAs and towards a more even distribution across the country—which includes the second-tier cities. 


\section{Literature Review}

\section{a) Housing Issues}

The literature review on immigrant housing issues revealed a number of complexities that immigrants face when attempting to access housing. These issues have been grouped into the following categories: affordability, adequacy and suitability, discrimination, spatial patterns and concentration, homeownership, refugees, and social networks. These categories are by no means exclusive but rather provide a means to group these issues in an effective way for ease of presentation. As will be explained below, immigrants’ housing issues are multifaceted and intertwined.

\section{i) Affordability, Adequacy and Suitability}

Housing affordability, as a concept for analysing housing problems and as a definition of housing need, is intrinsically tied to the mechanisms used to measure affordability, such as whether house prices are affordable in relation to incomes (house prices to income ratios) or a more specific measure of whether particular housing is affordable to certain groups (e.g. first time buyers). Moreover, additional measuring mechanisms, such as annual income necessary to purchase a house in a district or region, the residual income (left-over income after paying for housing), and access to finance (based on the size of the borrower's deposit and the associated loan to value ratio) all provide a measure of housing affordability (Whitehead et al., 2009; Hulchanski, 1995). In Canada, what had started a casual observation of house prices to income ratio patterns has turned into entrenched assumptions about what households are able to pay and what they should be paying. These observations were than translated into easy to use ratios of housing expenditures-to-income, referred to as the 'rule of thumb’ about the ability of households to pay for housing which have changed over the years from $20 \%$ in the 1950 s to $30 \%$ by the 1980s (Hulchanski, 1995). 
In Canada, housing is tied to the concepts of affordability, adequacy and suitability. Affordability pertains to the portion of income set aside for shelter, or more specifically a maximum percentage that a household should spend on housing; suitability refers to appropriate size of accommodation, while adequacy indicates the physical quality of the housing (Murdie \& Teixeira, 2004). For many immigrants, affordability is a major barrier in accessing housing. As a result, they are faced with limited options in finding suitable and adequate housing. Accessing adequate, suitable and affordable housing presents a first step in immigrants' integration (Murdie \& Teixeira, 2004). Upon finding the right neighbourhood and housing for themselves and their families, immigrants can then proceed with other aspects of their lives such as language training, education prospects, and the search for employment. As a result, the barriers that immigrants experience in housing delay their progress in other areas of social and economic integration. Chao's (1999) study of Ghanaian immigrants in Toronto's rental market revealed the barriers for newcomers with limited resources. Housing affordability was the major problem for this group and many were on the verge of becoming homeless. As a result, many resorted to living in crowded conditions in order to make housing more affordable.

\section{ii) Discrimination}

A number of studies point to the fact that discrimination is a major obstacle for immigrants in accessing housing (CERA, 2009; Murdie, 2003; Novac et al., 2002; Zine, 2002; Dion, 2001; Chao, 1999). Studies trace discrimination of immigrants in an attempt to access housing and highlight the multitude of forms that it can take, from level or source of income, to ethnicity, colour of skin, family size, gender, language, religion, and immigration status. The CERA (2009) study researched discrimination against lone parents, Black lone parents, individuals with mental illness, South Asian people and individuals receiving social assistance and found significant levels of discrimination associated with all five groups; all groups 
experienced moderate to severe discrimination in the range of 1 in 4 households while more than one third of housing seekers with mental illness were discriminated against. Novac et al. (2002) found a prevalence of discrimination among landlords, especially in less formal housing arrangements. Dion (2001) investigated the perceived personal and group discrimination among Jamaicans, Poles, and Somalis in Toronto, and found high levels of discrimination based on race, ethnicity, and religion, as well as on the basis of source and level of income. Zine's (2002) study found that two-thirds of respondents in Latin American and Muslim communities in Toronto found it "very difficult" to find an acceptable place to live, primarily because of a lack of income and reliance on social assistance. Additionally, gender discrimination was evident for immigrant women with young children, and immigrant women escaping abusive spouses were found to be at a high risk of homelessness (Farrell, 2005; Rose, 2004; Zine, 2002).

Immigrants also face barriers due to the size of their households (Murdie, 2002; Zine, 2002; Miraftab, 2000). Murdie (2002) found that Somalis, who were less successful in accessing housing than Polish immigrants in Toronto, were essentially forced out of the rental market because of the larger size of their families. Their households were composed of tightly knit family members, comparatively larger than Polish households, which prevented them from finding suitable accommodation in rental buildings due to the prevalence of smaller units. In Vancouver, Somalis and Kurds also faced major barriers in housing access due to the size of their households (Miraftab, 2000).

Immigrants are less aware of the housing conditions and quality of accommodation that they can expect to have, and lack knowledge of the legislative and customary practices relating to housing. This is compounded by a lack of language skills and little knowledge of Canadian culture (Lelup, 2005; Chan et al., 2005; Chambon et al., 1997). Ley and Smith (2000) highlight the connection between immigrant poverty and the inability to speak English or French. In 
addition, immigrants are experiencing increased economic deprivation, which consequently affects their housing access, since a lack of acknowledgment of their credentials and educational achievements makes finding adequate employment exceedingly difficult (Access Alliance, 2003).

\section{iii) Spatial patterns and Concentration}

Findings on spatial concentration of immigrants have been used as an argument for both the benefits and disadvantages of these spatial patterns. Concentrated settlements help immigrants form connections and aid one another in the settlement process; on the other hand, it has been argued that poverty and isolation associated with immigrant concentration prevent integration. Several studies have examined the influence of the immigrant settlement process and social networks on housing choices (Ghosh, 2007; Murdie, 2002; Owusu, 1998). The focus of these qualitative studies was on specific linguistic or ethno-cultural groups, such as Bengalis, Bangladeshis, Somalis, Poles, and Ghanaians in the Toronto CMA. The findings revealed the attractive force of social networks in concentrated settlement patterns such as post-war suburbs, census tracts, and even individual buildings, especially in the initial stages of the settlement process. The formation of these concentrations was mainly due to ethnic solidarity among immigrants, and a preference for one's own cultural and linguistic background in the face of a foreign culture. Murdie (2008) pointed out that although they can provide enhanced social capital through various forms of support from the ethnic community, there are, at the same time, implications of such concentrations for functional integration in areas such as language, education, and participation by immigrants in various aspects of the Canadian society.

iv) Homeownership

Homeownership for many immigrants creates an important sense of security and stability, and is a sign of social inclusion (Rose, 2004; Ray, 1998). Several authors have highlighted the 
importance of homeownership as a progressive step for immigrants in their housing trajectories (Skaburskis, 1996; Ray \& Moore, 1991). Immigrants, like Canadian-born individuals, aspire towards single-family homeownership. Not all immigrants fare equally in terms of homeownership; southern Europeans exhibited the highest rate of ownership while for Caribbean immigrants it was the lowest (Ray \& Moore, 1991). Chinese immigrants in Vancouver were most likely to be homeowners (Balakrishnan \& Wu, 1992). Positive factors that influence homeownership were found to be the length of time in Canada, family composition, ownership in the country of origin, income level, and perceived investment value (Balakrishnan \& Wu, 1992; Ray \& Moore, 1991), while homeownership rate is negatively affected by discrimination, refugee or single-parent households (Skaburskis, 1996), and a lack of value associated with homeownership by some groups, such as Ghanaians in Toronto (Owusu, 1998).

More recently, through a regression analysis, in Toronto, Vancouver, and Montreal, Haan (2005) found that housing for immigrants and for their Canadian-born counterparts has not been progressing in the same manner. While immigrants had an advantage over Canadian-born residents in the period from 1981-2001, the homeownership rate has since declined for immigrants. Even though the analysis accounted for family type, education, age, location, and labour market situation, it failed to provide an explanation for the declining immigrant homeownership rate. The major drawback of this study is that it did not take various ethnic or racial groups into consideration, whereas other studies have shown considerable variation of homeownership rates among immigrant groups.

In contrast, by utilising the Longitudinal Study of Immigrants in Canada (LSIC) data for the three major CMAs, Hiebert et al. (2006) revealed an improvement in the housing trajectories of immigrants over time spent in Canada, as they exhibited a higher tendency to purchase a home than their Canadian-born counterparts. However, this favourable outcome was not universally 
experienced; a number of newcomers, notably refugees and immigrants identified as Black, Arab, and West Asian, continued to struggle with problems of affordability and crowding even in the third wave of the LSIC survey.

v) Refugees

Refugees face unique challenges due to the fact that their experience is marked by physical or emotional trauma, and as a result are fleeing their country of origin with few resources, unprepared for the challenges that await them in a markedly different culture. Thus, they are highly vulnerable to homelessness. Their housing access is often marked by an entry into the cheapest available housing in the poorest residential areas, and accommodation is often shared and crowded (Murdie, 2010). On the upside, the likelihood of homelessness for refugees decreases with the increased size of one’s ethnic community (Hiebert, D’Addario, Sherrell \& Chan, 2005). They face a unique set of issues such as increased stress over family members left behind, discrimination in housing access due to their status, reluctance on the part of employers to hire them due to temporary work permits, insufficient medical treatment, lack of support during the refugee hearing process, and a high cost of landing status (Hunter, 1999).

vi) Social Networks

For the successful integration of immigrants into broader Canadian society, connections with other members of the community are equally usefully for an immigrant's housing search and subsequent well-being. In the initial stage of the housing search, immigrants rely on their own social networks, such as family and friends, rather than more formal settlement and housing resources. This can sometimes result in an extended and ineffective search for housing due to a lack of relevant and timely information. A study on immigrants in Vancouver found that the housing experience of newcomers was deeply influenced by the social capital of existing ethnic communities (Hiebert et al., 2005). Conversely, Bangladeshis in Toronto preferred to live closer 
to their friends and relatives (Ghosh, 2007). Most Bangladeshis moved from areas that lacked their ethnic compatriots to other areas where their social networks were strongest. Teixeira's (2006) study found that half as many Angolans compared to Mozambicans found their first accommodation through social networks rather than formal agencies. The lack of connections and friends in their new country led many Angolans to rely extensively on formal services, whereas the opposite was the case for Mozambican immigrants who relied on already established members of their community in Toronto.

\section{b) Findings in Second-Tier Cities}

The preceding research revealed the intricacies of immigrants' housing issues and the extent of the problems they face in their attempt to access housing. What follows is an examination of the housing issues in the context of second-tier cities in Canada. The aim is to analyze the literature on second-tier cities for facts that pertain to the key immigrant housing issues identified in the preceding section. Conclusions will then be drawn on how the second-tier cities fare in relation to these issues.

\section{i) Immigration and Housing}

The first concern for immigrants upon arriving in a new country is finding housing (Mattu, 2002). Access to affordable, adequate, and suitable housing is a necessary first step for immigrants and refugees alike, after which they look for employment, training and other services. Without housing that satisfies these criteria, immigrants face unsecure tenure, deteriorating health, reduced access to employment and education opportunities, and diminished social and family life (Carter, Polevychok, \& Osborne, 2009; Mattu, 2002). For immigrants in second-tier cities, just as in the three largest cities, permanency in their housing is delayed, as it typically takes several years for them to settle into more stable housing. In the Lower Mainland 
of British Columbia, it takes three to four years for immigrants and refugees to obtain long-term housing upon arrival (Mattu, 2002). Likewise, in Winnipeg, a study of refugees revealed that the population was highly mobile; even though a significant majority of respondents arrived within the year prior to the study, it nevertheless found that $93 \%$ of immigrants had already lived in more than one location since arrival and $24 \%$ had lived in three or more locations. For immigrants, at least in the initial stages, the housing was largely transitional, with the average length of stay being twelve weeks (Metropolis Project, 2007).

Most immigrants chose second-tier cities based on economic factors, such as job availability or economic strength, the presence of social networks (family and friends), and quality of life factors, such as climate, city size, lower cost of living, and affordability, especially in comparison to the larger centres. Hence, a driver for immigrant settlement in British Columbia's smaller centres, such as Kelowna, Vernon, and Penticton, as well as in Windsor/Essex in Ontario, was their desire to be close to family members already established there, as well as better employment opportunities (Teixeira, 2010; Anucha, Smylie, Mitchell, \& Omorodion, 2007). In addition, immigrants in Windsor/Essex noted the lower cost of living, milder climate, and proximity of employment opportunities in the United States as reasons for their settlement decision. Many immigrants were deterred from moving to the City of Toronto because they perceived other destinations, such as Kitchener-Waterloo and Hamilton, as more attractive, safer, and more affordable. High costs of living dissuaded many immigrants from settling in Toronto, many of whom subsequently chose Hamilton as their settlement destination (Bezanson, 2003; Satzewich \& Shaffir, 2007).

Several studies have attempted to quantify the reasons behind immigrant settlements in second-tier cities, with mixed results (Di Biase \& Bauder, 2005; Hyndman, Schuurman, \& Fiedler, 2006; Dumais, 2009). A quantitative and qualitative analysis by Di Biase and Bauder 
(2005) examined the settlement patterns of immigrants in Ontario's second- and third-tier cities, and rural areas. The study triangulated three methods of analysis. First, the spatial settlement distribution of immigrants was mapped using Census data. Then, a multivariate regression, using the Census data, investigated the link between settlement location, labour market, and housing characteristics. Finally, the interviews investigated the location choices of immigrants in areas outside of Toronto. While multivariate regression was unable to fully explain the motivations behind immigrant settlement patterns, the interview findings confirmed that the success in attracting immigrants lies in the provision of settlement services, employment, and adequate and timely information.

Conversely, the two other studies, by Hyndman, Schuurman, and Fiedler (2006), and Dumais (2009), also attempted to quantify the reasons behind immigrant settlement in secondtier cities by using the LSIC data. Both studies researched the attractiveness of smaller cities by developing a locational index for six second-tier cities in British Columbia, and five in Ontario. The studies were based on the LSIC findings that enumerated the reasons that immigrants gave for settling outside the Toronto, Vancouver, and Montréal CMAs: the presence of family and friends, 39.1\%; job and business prospects, 41.5\%; education prospects, $13.3 \%$; and lifestyle, 6.1\%. The four categories were then established by using quantitative data as proxies. For example, the CMAs' percentage of immigrants from 1971-2001 and the percentage of recent immigrant growth from 1996-2001 were used for the family and friends category. The studies confirmed that immigrants were attracted to cities where friends and family or other immigrants lived, while also revealing that the attractiveness of a city is primarily related to its size. The Hyndman, Schuurman, and Fiedler study completely omitted the category of housing from the research, but considered climate as the only lifestyle factor relevant to the locational preferences of new immigrants. The Dumais study elaborated further on the lifestyle category by arbitrarily 
splitting it into four elements—city size, safety, climate, and housing affordability—while maintaining the overall importance of the category at only $6.1 \%$. These studies assumed the relative unimportance of housing even though several qualitative studies mentioned earlier revealed the importance of lifestyle factors, such as climate, city size, lower cost of living, affordability, and availability of services, without assigning a value for each factor in immigrant settlement decisions.

Despite difficulties in distilling the exact factors behind immigrant settlement patterns, some second-tier cities have nevertheless performed well in attracting and retaining immigrants. The attractiveness of second-tier cities is evident from the examples of the Waterloo Region and the City of Hamilton. In Waterloo, as many as $40 \%$ of immigrants settled through secondary migration from other parts of the country (Abu-Ayyash \& Brochu, 2006). In Hamilton, the number of secondary migrants was even higher, as $50-75 \%$ of immigrants didn't choose the city initially, but rather moved there subsequently. Hamilton also scored high in terms of immigrant retention rate at $133 \%$, which measures the number of immigrants who indicated the city as the destination of choice compared to the actual number of them who initially settled in the city (Satzewich \& Shaffir, 2007). Other second-tier cities also scored higher in terms of immigrant retention rate—London (114\%), Ottawa (103\%), Calgary (93\%), and Edmonton (91\%)— compared to the CMAs of Toronto (84\%), Vancouver (89\%), and Montreal (86\%). Quality of life factors, such as a welcoming social environment and good climate, were cited by almost half the immigrants as main reasons for staying in second-tier cities such as Calgary and Edmonton (Derwing \& Krahn, 2006).

Some authors have argued that the presence of a university in a second-tier city acts as a draw and provides enhanced networking and employment opportunities for immigrants. WaltonRoberts (2011) found, based on Kitchener-Waterloo, that higher education institutions act as a 
catalyst of change by introducing greater ethnic and cultural diversity, an important draw for immigrant talent that ultimately creates linkages and connections in the local economy, and finally that higher education institutions mitigate against broader discriminatory behaviours (Walton-Roberts, 2011). This was the experience of Bangladeshi immigrants in KitchenerWaterloo, who utilized higher educational opportunities in local institutions as a successful settlement strategy. This study found that Bangladeshis in Kitchener-Waterloo had comparatively higher education than the local population and also fared better, both in employment opportunities and larger community acceptance, than their ethnic compatriots in Toronto (Propa, 2007). This was largely, in their view, due to the fact that they practiced Islam, which exposed them to discrimination, and their perceived lower social status compared to other ethnic groups in both Toronto and Montréal. Their positive settlement experience in KitchenerWaterloo ultimately resulted in most members of the group having a progressive housing trajectory by quickly moving into homeownership from an initial rental accommodation.

\section{ii) Refugees}

Research on refugees in largest metropolises has found that, as a whole, they tend to fare worse than other immigrants in terms of housing trajectories and experiences due in large part to their overall lower education, income levels, and language skills, which contributes to their slower economic and social integration. In addition, many refugees face the additional burden of emotional, physical, or health trauma as a result of previous experiences in their country of origin. Thus, it is interesting to find that some second-tier cities have more refugee settlers, on a proportional bases, than the three largest CMAs. London, for example, has one of the highest populations of refugees per capita in Canada with 27\% of immigrants being refugees. Similarly, 18.3\% of the Waterloo Region’s immigrants are considered refugees. Comparatively, the Canadian average is $11 \%$ of refugees in the overall immigrant population and $9 \%$ in Ontario 
(Brochu \& Abu-Ayyash, 2006; Abu-Ayyash \& Brochu, 2006). Ottawa has the highest proportion of refugees among immigrants at $29 \%$ compared to $11 \%$ for Toronto, $10 \%$ for Vancouver, and 19\% for Montreal (Mohamud, 2007). In Hamilton, family class immigrants (34\%) and refugees (20\%) comprised a larger share of immigrant settlers compared to the national averages of $29 \%$ and $11 \%$, respectively (Satzewich \& Shaffir, 2007). While there is no comparable comprehensive research on refugees in second-tier cities it can nevertheless be inferred from the available data in the largest metropolises, that they fare worse than non-refugee immigrants.

\section{iii) Homeownership}

A progressive housing trajectory for immigrants means denoting changes that occur over time while simultaneously tracking accommodation choices that are in some way better than the previous housing situation. In this regard, homeownership is considered a positive and progressive housing trajectory to which many immigrants aspire regardless of whether they live in the largest or second-tier cities. A unique longitudinal study of immigrants tracked changes of the first cohort, comprising 1,000 respondents, that settled in Quebec after the provincial government took over the responsibility from the federal government for immigration and integration programs in the 1990s. In terms of housing trajectory, immigrants gained greater access to homeownership with $36 \%$ of respondents being homeowners ten years after settling in the province. A dispersal of immigrants also occurred, from the Island of Montreal to the surrounding cities and beyond, mostly after the third year after arrival. Moreover, no differences in terms of homeownership rates were observed due to the class of immigrants, age, or gender; nevertheless, a higher level of education did predispose such respondents to higher homeownership rates and faster access (Renaud et al., 2003).

However, other authors have observed that not all homeownership is progressive, and that some immigrants may be pushed into homeownership prematurely mainly because of lack of 
any other housing options, which subsequently puts them at risk for homelessness due to a higher allocation of income (more than 30\%) for housing payments. This was the situation that Preston et al. (2009) found in York Region, where the lack of affordable housing options, dominance of homeownership as a tenure option, increased affordability compared to Toronto, and comparable rental and homeownership pricing led many immigrants to become homeowners. As a result, many immigrant households (31\%) lived in multiple family arrangements so that they could afford the rent and make homeownership more affordable.

\section{iv) Housing Information}

The importance of timely and accurate housing information is essential for immigrants in their settlement process. Several studies have found this to be a more acute problem in secondtier cities, such as London, B.C.'s Lower Mainland, and Calgary, among others, mainly due to the lower level of service provisions and a lack of specialized cultural and linguistic knowledge that caters to diverse immigrant ethnic groups (Brochu \& Abu-Ayyash, 2006; Mattu, 2002; Denso \& Grant, 2000; Tanasescu et al., 2009). Finding suitable and affordable housing in B.C.'s Central Okanagan Valley, one of the most expensive markets in the country, proved to be a challenge for newcomers. Almost half the respondents in Kelowna, Vernon, and Penticton had to rely on their own social networks_-family and friends—in their search for housing, while less than a third relied on housing service providers. The respondents identified service gaps pertaining to immigrants and a lack of reliable and timely information in their housing search (Teixeira, 2010). Lack of language skills also presents an initial barrier for immigrants in their housing search, as well as in dealing with settlement agencies and caseworkers. Consequently, immigrants do not acquire relevant knowledge on how to obtain housing and what their legal rights are in dealing with landlords. Furthermore, even the services they know of tend not to be very useful to them. Refugees in Surrey were also in a situation where they lacked knowledge of 
the housing services available to them, both from the provincial level as well as from the city itself (Sherrell, 2009).

On the other hand, research on the attractiveness of second-tier cities for immigrants found that the provision in the areas of immigrant settlement, employment (immigrant skills coordinated with economic development strategies), adequate information about services, and ESL education are critical for success in smaller centres (Abu-Laban, 1999; Abu-Ayyash \& Brochu, 2006; Di Biase \& Bauder, 2005; Walton-Roberts, 2004). A qualitative study on housing in five second-tier cities—-Kitchener, Ottawa, London, Windsor, and Hamilton—employed interviews with key municipal and service provider stakeholders. They singled out translation, the absence of dedicated units, and the scarcity of large units as the largest outstanding problems, while settlement agencies identified initial settlement assistance, particularly for refugees, as the main obstacle related to housing for newcomers (Wachsmuth, 2008).

\section{v) Barriers and Discrimination}

Discrimination is a persistent burden that makes access to housing more difficult for immigrants and delays their integration and settlement process. Immigrants face discrimination from landlords who often resort to racial and cultural stereotyping, and are not willing to acknowledge the additional burden they thus impose on this already vulnerable population. In this regard, immigrants unfortunately do not fare better in second-tier cities than they do in the three largest cities. African immigrants in Calgary encountered formidable discrimination in the housing search due to racism, with immigrant renters bearing the brunt of the discrimination relative to immigrant homeowners (Denso \& Grant, 2000). Similarly, immigrant households in Central Okanagan's cities experienced discrimination from landlords who refused to rent to large families, and who questioned immigrants’ cultural practices, such as their cooking (Teixeira, 2010). In contrast, Afghani refugees in Kitchener-Waterloo didn’t experience barriers related to 
their ethnicity, religion, or skin colour when accessing housing. However, their refugee status as well as their health emerged as issues in the housing search (Bezanson, 2003). These findings on discrimination underscore the fact that, for immigrant settlement and housing success, the presence of a welcoming and unprejudiced social context is just as important as a positive economic one.

For refugees in Winnipeg, the settlement experience was additionally strained by competition with another marginalized group, Aboriginals, also in search of affordable but poorquality accommodation within a decaying and crime-ridden inner city. Low vacancy rates and limited availability of social and public housing resulted in competition between the groups for scarce housing. As a result, landlords were in a better position to pick and choose preferred tenants, which invariably tended to be refugees. Since refugees received support from private or government sponsorship, the payout for landlords was greater and they were thus favoured. Associations of crime, drug use, and tenant problems with Aboriginals also resulted in preferential housing access for refugees (Carter, 2010). This unfortunate situation of marginalized groups competing for limited housing options creates stress for both groups and pits them against one another, which is an added burden of discrimination on top of the one directed at them from landlords and unwelcoming community members.

Just as in the three largest cities, immigrants and refugees in larger households faced difficulties obtaining suitable housing in B.C.s Lower Mainland, Ottawa, and KitchenerWaterloo, among others, in comparison to the native-born population (Mattu, 2002; Boucher, 2007; Bezanason, 2003). In Winnipeg, the larger sized refugee households also faced difficulties finding suitable accommodation. The refugees' household size of 3.7 persons per household significantly exceeded the city's average of 2.4 persons per household, which created challenges in finding apartments with enough bedrooms to accommodate the households. In addition, $12 \%$ 
of the refugee population were in households that included six or more persons (Carter, 2010). For Winnipeg's refugees, apartment housing was the norm for over $80 \%$ of respondents, with 70\% living in apartments with two bedrooms or less (Metropolis Project, 2007). These findings are even more problematic in second-tier cities given the lower level of settlement services offered compared to the three largest cities, the proportion of refugees among immigrants in some cities as noted earlier, and a general lack of suitable units to accommodate larger households.

Immigrants, and even more so refugees, are affected by high levels of poverty in their housing search in both major metropolises and second-tier cities. In Winnipeg, larger refugee households were especially vulnerable and experienced high levels of poverty (Carter, 2010). Low income was prevalent among the refugees, with the average at just under $\$ 21,000$, or twoand-a-half times less than the city's average. Overall, 86\% of refugees had income below the LICO for Winnipeg. As a result, a high proportion (77\%) of received a portion of their income from government sources, with $41 \%$ completely relying on government assistance (Metropolis Project, 2007). In contrast, immigrants in the Waterloo Region’s municipalities of Kitchener, Waterloo, and Cambridge experienced lower poverty rates than immigrants as a whole on a provincial level (Abu-Ayyash \& Brochu, 2006). This finding is more relevant due to the fact that refugees are included in the overall category of immigrants, and also because the Waterloo Region has one of the highest proportions of refugees in the country, yet its poverty level is lower than the provincial average.

Immigrants of visible minority status experienced considerable discrimination in their housing and employment search. These findings were evident in both large and second-tier city studies in Toronto, Peel Region, and Hamilton, as well as a study in Windsor/Essex (Kilbride, Webber, Wong \& Amaral, 2006; Anucha, Smylie, Mitchell, \& Omorodion, 2007). The study in 
Windsor/Essex found that visible minority status was the most reliable predictor of core housing need among immigrants. Among visible minority immigrants, 20.5\% are in core housing need compared to $17.9 \%$ non-visible minority immigrants, due to the issue of affordability. At the same time, a much smaller proportion indicated adequacy as a reason behind the core housing need, with $3.3 \%$ of visible minority immigrants compared to $4.5 \%$ of non-visible minority immigrants. In terms of core housing need related to the issue of suitability, $16.1 \%$ of visible minority immigrants considered this an issue compared to only $4.2 \%$ of non-visible minority immigrants. The same study found that certain visible minority groups fared worse as immigrants than their Canadian-born counterparts; for example, the largest proportion of immigrants in core housing need were of Arab/West Asian background, while for the Canadianborn population the largest incidence of core housing need was among Blacks. Among visible minority immigrants, the largest proportion that experienced affordability and adequacy as housing issues were Black immigrants, while South Asians were the largest population with suitability as a main reason behind their core housing need (Anucha, Smylie, Mitchell, \& Omorodion, 2007). As Brochu and Abu-Ayyash (2006) found in London, "the darker an immigrant's skin, the stronger his or her accent, the more deviant his or her style of dress from Canadian custom, and the more his or her name deviates from normative European names, the less likely he or she is to be accepted” (Brochu \& Abu-Ayyash, 2006).

\section{vi) Affordability, Adequacy, and Suitability}

In line with the findings in the three major cities, immigrants in second-tier cities also faced problems due to unaffordable, unsuitable, and inadequate housing. These findings were evident in many second-tier cities, such as for immigrants in B.C.s Lower Mainland, Africans in Calgary, and refugees in Winnipeg and Surrey (Mattu, 2002; Denso \& Grant, 2000; Carter, 2010; Sherrell, 2009). For example, one-third of African immigrants in Calgary were living in 
dwellings with structural issues, with an average room occupancy ratio three times higher than the city's average, and more than half faced problems of affordability by spending more than $30 \%$ of their income on housing. Also, African immigrant renters were significantly more affected by the affordability problem than immigrant homeowners (Denso \& Grant, 2000). Similarly, Cater (2010) found that almost 50\% of refugee households in Winnipeg were paying more than $30 \%$ of their income on housing, while $12 \%$ were paying more than $50 \%$ on housing. Likewise, the affordability issue for refugees in Surrey was widespread; 15 out of 22 respondents were spending more than $51 \%$ of their income on housing while seven out of 22 respondents had to allocate more than $75 \%$ of their monthly income on housing. The study found that a substantial number of refugees were thus at risk of homelessness, and "couch surfing," indicative of unstable or temporary living arrangements, was also on the rise. Significant overcrowding was found in many refugee households in Surrey. It was not uncommon to find four to five people in a one-bedroom unit, or six to eight people in a two-bedroom unit (Sherrell, 2009).

\section{vii) Income Levels}

Low income levels for immigrants act as a barrier in obtaining housing, and this finding was evident in both large and second-tier cities. Immigrants, and particularly refugees, in B.C.'s Lower Mainland, as well as Afghani refugees in Kitchener-Waterloo, experienced housing barriers due to low income (Mattu, 2002; Bezanson, 2003). Additionally, for Afghanis, the source of their limited income (government assistance) created an additional barrier. A study by Denso and Grant (2000) found that Africans in Calgary had low earnings, well below the city's average at the time, despite high employment and education levels. This severely limited their choice of housing and exposed them to discrimination during the housing search. In Surrey, refugees faced difficulties reconciling their low incomes, whether from employment or 
government assistance, not only with high rents but also with the requirement to repay Federal Government travel loans within a year after arrival (Sherrell, 2009).

In contrast, a quantitative study by Statistics Canada (Bernard, 2008) used a linear regression model to examine the income advantage of immigrants in smaller urban centres (second- and third-tier cities) across Canada when compared them to the three largest cities, by looking into the class of immigration, the number of years spent in Canada, education level, country of origin, and language proficiency. The Longitudinal Administrative Databank containing T1 tax information, which also encompasses the Longitudinal Immigration Database, provided the input for the survey. The study found that in smaller centres the initial disadvantage of immigrants, in terms of income, generally disappears after a few years of living in Canada. In contrast, in the largest urban centres (Toronto, Montréal, Vancouver CMAs), immigrants faced a larger initial income disadvantage, and subsequent income increases were not enough for them to close the gap. Better economic integration of immigrants outside the largest urban centres was evident even after taking into consideration the differences in terms of immigrants' education upon arrival, prior ability in an official language, admission class, and country of origin. This study, despite being quite comprehensive in terms of providing quantitative proof of the income advantage of smaller cities for immigrants, did not take into account the immigrants' outcomes in terms of housing.

\section{viii) Employment}

Lack of employment is seen as a major barrier in accessing housing in second-tier cities because immigrants need to prove they can afford the rent; this is consistent with findings in the three largest cities. Even though is not a legal, the common requirement of a security deposit for rental accommodation presents a barrier in housing access (Mattu, 2002). Mattu (2002) found, in Lower Mainland of British Columbia, that immigrants and refugees typically had to provide a 
sum that covered a period of six months’ rent, which for some was an exorbitantly high lump sum given that fact that they were just starting off in a new country. In Windsor/Essex, lack of employment was a major obstacle to housing access despite the proximity of opportunities that existed at the time across the border in the United States. Lower cost of living and rental rates in Windsor/Essex were insufficient to compensate for the lack of employment opportunities, which negatively affected immigrants’ access to housing (Anucha, Smylie, Mitchell, \& Omorodion, 2007). In Surrey, high unemployment among refugees was prevalent with only eight out of 24 respondents reporting being employed. Additionally, more than a half of respondents were relying on government assistance for their income (Sherrell, 2009).

In contrast, the right social and economic context can have a positive effect on immigrant attraction, retention, and integration in second-tier cities. Walton-Roberts (2004) found that immigrants in Squamish, B.C., had a positive settlement experience due to availability of jobs, mainly in the service industry, which enabled social integration in the workplace, and also because of the presence of a wider social support network created through family class immigration. The relative success of immigrants in Squamish underscores the importance of planning for immigrant settlement in the larger context of service provision, the creation of welcoming communities, and economic development.

\section{ix) Social Networks}

For immigrants, reliance on social networks of family and friends proved to be the prime resource for housing information in both second-tier and largest cities. Even for immigrants who were progressing in their housing careers, such as Portuguese immigrants relocating to singlefamily dwellings in Mississauga, reliance on ethnic communities proved invaluable. They relied heavily on ethnic sources of information in their housing search, particularly Portuguese real estate agents. This was partly due to the language barrier that many of these immigrants faced, 
and partly to the inherent cultural preference to live near other members of their ethnic community (Teixeira, 2007). In the case of Filipino immigrants in second-tier cities, Lusis and Bauder (2008) demonstrated how immigrant networks at various geographical scales helped with the settlement process. In second-tier cities, immigrants relied on family and friends' social networks in finding housing and employment upon arrival. They also reached out to strangers within their own ethnic community, and Filipino associations at times provided additional contacts. At the larger transnational scale, immigrant networks, enabled by the internet, were formed as the primary sources for settlement information on second-tier centres in Canada. Regional-level ties, such as social networks between Filipino immigrants in Toronto and secondtier cities, appeared to be weak. Most Filipino immigrants didn’t have a favourable view of Toronto, due to perceived lack of safety, less personal and friendly reception of Filipino immigrants, and exploitative nature of employment in Toronto due to informal nature of many employment arrangements, even though they had members of their social networks in the city (Lusis \& Bauder, 2008).

\section{x) Diminishing Supply of Affordable Units}

Lack of affordable units is a ubiquitous problem that affects both the largest and secondtier cities due to federal and provincial disinvestment in the affordable housing sector (Carter, 2005; Hulchanski, 2003). In addition, some second-tier cities experience additional pressures on housing affordability due to specific local characteristics. In Ottawa, much of rental housing stock was lost in the 1970s due to the urban renewal schemes or gentrification (Boucher, 2007). Immigrants settling in B.C. Central Okanagan’s three major cities of Kelowna, Vernon, and Penticton experienced a significant shortage of public and non-profit housing despite the provincial government's efforts to construct more affordable housing. The problem was more acute due to the fact that Central Okanagan is one of the most expensive housing areas in the 
country, either to buy or rent, and the vacancy rate is low. As a result, more than half of all immigrants found their first accommodation, often of poor quality, in the basements of family and friends, (Teixeira, 2010). In Alberta, increasing market rents driven largely by energy sector wealth, lack of new social housing, conversions of old stock rental apartments, and reduction in income support payments significantly limited the availability of rental units for immigrants (Gurnett, 2010). Additionally, the stagnant housing supply of affordable units in London complicated the housing search process for immigrants due to the presence of a large student body essentially competing for the same scarce housing (Brochu \& Abu-Ayyash, 2006).

\section{xi) Access to Amenities and Services}

Immigrants in second-tier cities expressed a strong preference for housing near their respective ethnic communities, but also near services, such as schools, transportation, and shopping, in response to questions that asked them to express what they, at the time, liked about their housing arrangements (Nadeau et al., 2012; Bezanson, 2003; Wilson, 1992). Even though immigrants expressed a preference for amenities, services, and employment in proximity to housing, these tend to be in proximity to concentrated apartment block settlements, as in Toronto's isolated central city blocks or post-war suburbs, which is often the only housing option available to immigrants, at least in the initial stages of their settlement process. While this type of housing arrangement may be a better option, in comparison to their situation in their home country, immigrants are often unaware of the quality and condition of housing they can expect to have in the new country, and this type of concentrated housing might have implications for their functional integration (Murdie, 2008). Immigrants tend to lack mobility, at least in the initial settlement stage, and thus favour locations in close proximity to amenities and services. In the case of Afghani refugees in Kitchener-Waterloo, they indicated proximity to ethnic social networks as a drawing factor for settling in the region, but also exhibited a settlement pattern that 
was concentrated in one census tract with low rent apartments close to transit and shopping. Studies in Calgary found that immigrants tended to live in or near the core of the city with amenities, such as shops, businesses, restaurants, and transit in close proximity to their housing (Tanasescu et al., 2009; Wilson, 1992). These findings indicate that immigrants value the proximity of housing to their respective ethnic communities, but also value access to services and amenities. In some cases, however, immigrants had to settle for what was available, such as in Winnipeg's crime-ridden and decaying inner city, which had affordable rental housing (Carter, 2010), or Kelowna, where immigrants found housing in the largely substandard basements of family and friends with limited services and amenities (Teixeira, 2009). This emphasizes the need for planners and policymakers to grapple with the realities of a physical and housing realm, and foster change enabling a comprehensive city context that serves immigrants’ needs.

\section{c) Summary of the Literature Review Findings}

The research on immigrant housing issues demonstrates that there is some overlap of conditions between the three major CMAs and second-tier cities, with some distinct differences at the same time. The research on housing issues, such as discrimination, lack of affordable housing, importance of social networks in the housing search, and a more challenging situation for refugees in comparison to other immigrants, demonstrated that immigrants in second-tier cities experience the same problems as immigrants in the largest metropolises. The fact that residential trajectories of stigmatized ethnic minorities are deeply affected by discrimination and that shortage of affordable housing exacerbates this problem, as Simon (1998) has found, speaks to the severity of the systemic housing problem across the country being increasingly felt by newcomers. 
The research also found some distinct differences among different cities and contexts. Some second-tier cities, such as Hamilton, London, and Ottawa among others, have a comparatively higher immigrant retention rate, and also act as a destination for secondary migration. Second-tier cities are more attractive than the three major metropolises not only because of economic opportunities and the presence of family and friends, but also because of quality of life factors, such as climate, city size, availability of services, lower cost of living, and also the perceived safety, attractiveness, and affordability of second-tier cities when compared to the big metropolises such as Toronto.

The findings on second-tier cities also demonstrate that some immigrants encounter progressive housing trajectories by improving their housing situation, in accordance with majority of the Canadian-born population, through entry into homeownership. However, this process is not without its drawbacks; for some, they may be achieving this goal out of necessity rather than actual ability because of the lack of other housing alternatives, which was the situation that confronted many immigrants in York Region. It seems that immigrants, much like Canadian-born residents, are caught in a socially divided society that impels them to increase their societal standing, through what Musterd (2003) calls bargaining power through consumption, with housing being a major part of this expression.

Higher education institutions in second-tier cities can act both as a draw and a deterrent for immigrant settlement. On the one hand, they provide employment and connections in the knowledge economy, which acts as a draw for immigrants with the right skills. On the other hand, large student bodies effectively compete with immigrants for the same scarce affordable housing. These two forces can act at cross-purposes and their impact needs to be researched further in the appropriate context and in more depth. 
In terms of income, immigrants in second-tier cities appear to have an advantage over immigrants in the largest metropolises (see Bernard, 2008). However, even though these findings were demonstrated at the overall Canadian level, it is important to note that specific local economic and housing constraints in the second-tier cities, such as Calgary and Kelowna for example, increasingly shape both the housing context for immigrants as well as their economic well-being. Several studies, such as Ley et al. (2001), Bauder, Waters and Teo (2001), and Murdie and Teixeira (2004), have demonstrated how immigration has contributed to inflationary pressures on property values. While immigration is necessary for economic growth sustenance and helps fuel the growth of housing value, simply increasing immigrant numbers, in the absence of adequate affordable housing policy, creates an ever-increasing affordability strain for newcomers.

The lack of timely, adequate, and relevant settlement and housing services appears to be an issue in second-tier cities, more so than in the three largest cities. The research, on the other hand, confirms that provisions in the areas of immigrant settlement, employment (immigrant skills coordinated with economic development strategies), adequate information about services, and ESL education are critical for success in smaller centres. This disconnect highlights the need for more relevant and accessible immigrant services particularly in the face of the government's desire for dispersal; otherwise, the absence of adequate settlement provisioning implies low government priority for their genuine accommodation and dispersion.

This research also demonstrated the lack of comprehensive research on housing in second-tier cities, unlike readily available research on Toronto, Vancouver, and Montréal. Qualitative studies in second-tier cities mainly focus on a particular ethnicity or immigration class, such as refugees. On the other hand, quantitative studies, such as LSIC, focus on immigrants' housing issues and trajectories in the overall Canadian context. In order to bridge 
this gap, further research should be directed to studies in second-tier cities at both the city level as well as the more nuanced ethnic group level. In addition, longitudinal research in second-tier cities would be able to track immigrant housing trajectories and experiences over time. This research is necessary in order to better inform both housing and immigration policy recommendations at the national, provincial, and city levels, as all levels of government are keenly interested in the benefits provided by immigration. This further research would also help planners, the business community, and settlement organizations create more engaging and welcoming communities for immigrants.

In its next steps, this research will focus on Census data, summarized in the CMHC's 2006 and 2001 Census Housing Series Issue 7 (CMHC, 2010; CMHC, 2004) as well as CMHC’s (2012) rental apartment market indicators, in order to extract the housing data for immigrants in second-tier cities, such as income, core housing need, ownership rate, and affordability, and compare them to the metropolitan CMAs of Toronto, Vancouver, and Montréal. The aim is to augment the preceding findings and broaden the related discussion. Likewise, a literature review of policies and programs pertaining to housing and immigrant dispersal will examine their effects on second-tier cities in Canada. Constraints and opportunities pertaining to housing and immigrant settlement in second-tier cities will be examined in order to contribute to the discussion on housing and immigration policies. 


\section{Income, Core Housing Need, Homeownership Rate, and Affordability}

The preceding section on immigrant housing in second-tier cities identified several issues that affect immigrant's access to housing. The immigrant housing issues were found to be access to housing information, diminishing supply of affordable units, barriers and discrimination, income levels, access to amenities and services, employment, affordability, adequacy, suitability of housing, availability of social networks, and homeownership rate. Several issues such as income, core housing need, homeownership rate, and affordability will be explored here through the analysis of Census housing data. These particular issues will be explored further in order to augment the findings of the preceding section as they lend themselves to quantitative data collection. The data, already presented in the CMHC’s 2006 and 2001 Census Housing Series Issue 7 (CMHC, 2010; CMHC, 2004), have been organized and tabulated in order to perform a comparative analysis. Additionally, CMHC’s (2012) data showing rental market indicators for apartment structures with three or more units in all 33 CMAs across Canada is presented. The ultimate aim is to draw quantitative comparisons between Canada's second-tier cities and the three largest metropolises on the issues of income, core housing need, ownership rate, and affordability.

The following analysis will examine all second-tier cities (defined earlier) and the three largest metropolises which comprise all 33 CMAs in Canada. Statistics Canada defines a Census Metropolitan Area (CMA) as an area consisting of one or more neighbouring municipalities totalling a population of at least 100,000 , of which 50,000 or more live in the urban core. In 2006, six new areas became CMAs: Moncton (N.B.), Barrie (Ont.), Brantford (Ont.), Guelph (Ont.), Peterborough (Ont.), and Kelowna (B.C.) (Statistics Canada, 2012a).

The CMHC’s Census Housing Series Issue 7 data examines the housing conditions of immigrant households in Canada. Immigrant households are defined as households whose 
primary maintainer is an immigrant to Canada. The primary household maintainer is the first person identified by Census respondents as being responsible for household payments and who normally contributes the greatest amount toward the payments for shelter expenses (CMHC, 2010; CMHC, 2004).

This chapter analyzes the affordability issue in second-tier cities in Canada by employing Statistics Canada’s shelter-cost-to-income ratio (STIR). Statistics Canada defines the average STIR as the proportion of total before-tax household income spent on shelter. The shelter-costto-income ratio is calculated for each household individually by dividing its total annual shelter cost by its total annual income. The average STIR is then computed by taking the average of the individual households' STIRs. It is worth noting that the average STIR is not calculated by dividing the average shelter cost by the average household income (Statistics Canada, 2009).

Additionally, an issue of core housing need is examined in both second-tier and the three largest cities. A household is in core housing need if its housing does not meet one or more of the adequacy, suitability, or affordability standards and it would have to spend 30 per cent or more of its before-tax income to pay the median rent of alternative local market housing that meets all three standards (CMHC, 2010; CMHC, 2004).

CMAs across Canada have an unequal distribution of immigrants. The top ten municipalities, including the three largest cities as well as second-tier cities of Ottawa-Gatineau, Calgary, Edmonton, Winnipeg, Hamilton, Kitchener, and Windsor received 90\% of all immigrants who settled in Canada in 2006 (Murdie, 2008). These cities also comprised 54\% of the country's population. The first column in Table 1 denotes the percentages of immigrant households across all 33 CMAs in relation to the total number of households in each city. Second-tier cities are ranked according to the percentage of immigrant households while the 
three largest metropolises (Toronto, Vancouver, and Montreal) are also ranked and presented together.

\begin{tabular}{|c|c|c|c|c|c|c|c|c|c|}
\hline \multicolumn{10}{|c|}{ Household statistics by household immigrant status. Census Metropolitan Areas, 2006} \\
\hline CMAs & 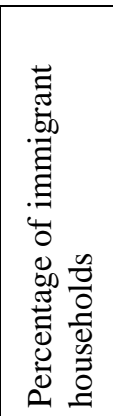 & 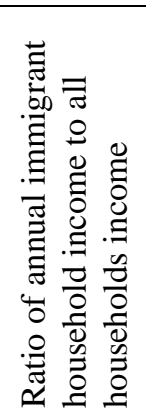 & 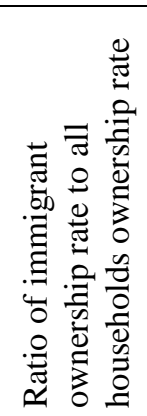 & 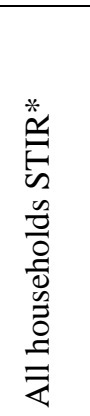 & 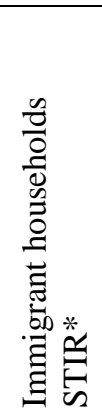 & 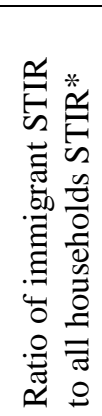 & 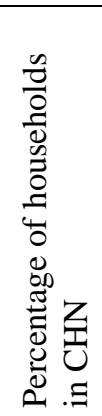 & 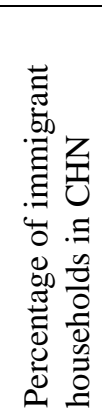 & 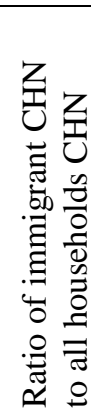 \\
\hline Hamilton & 30.8 & 91.8 & 103.5 & 21.9 & 21.6 & 98.6 & 12.9 & 15.1 & 117.1 \\
\hline Kitchener & 27.8 & 92.7 & 103.2 & 21.3 & 21.5 & 100.9 & 10.3 & 12.1 & 117.5 \\
\hline Abbotsford & 27.6 & 98.0 & 108.3 & 23.6 & 23.1 & 97.9 & 12.9 & 14.1 & 109.3 \\
\hline Windsor & 27.0 & 97.3 & 100.8 & 20.8 & 20.8 & 100.0 & 12.7 & 14.8 & 116.5 \\
\hline Calgary & 26.2 & 88.1 & 105.3 & 21.2 & 21.4 & 100.9 & 9.0 & 11.7 & 130.0 \\
\hline Guelph & 25.0 & 100.1 & 107.9 & & & & 11.8 & 12.3 & 104.2 \\
\hline $\begin{array}{l}\text { St. } \\
\text { Catharines- } \\
\text { Niagara }\end{array}$ & 23.6 & 96.3 & 105.5 & 21.5 & 20.6 & 95.8 & 12.2 & 11.2 & 91.8 \\
\hline London & 23.1 & 92.2 & 105.5 & 22.4 & 22.4 & 100.0 & 12.8 & 15.7 & 122.7 \\
\hline Victoria & 22.9 & 99.0 & 112.7 & 23.1 & 21.8 & 94.4 & 12.4 & 12.0 & 96.8 \\
\hline Oshawa & 22.3 & 96.7 & 106.5 & 21.8 & 21.8 & 100.0 & 11.6 & 13.2 & 113.8 \\
\hline Edmonton & 21.9 & 93.8 & 105.8 & 20.7 & 20.6 & 99.5 & 10.6 & 12.9 & 121.7 \\
\hline Winnipeg & 20.4 & 98.0 & 103.4 & 20.4 & 19.6 & 96.1 & 10.4 & 10.5 & 101.0 \\
\hline $\begin{array}{l}\text { Ottawa- } \\
\text { Gatineau }\end{array}$ & 20.1 & 95.0 & 96.4 & 20.5 & 21.8 & 106.3 & 12.1 & 19.3 & 159.5 \\
\hline Kelowna & 18.3 & 87.4 & 107.4 & & & & 11.1 & 11.1 & 100.0 \\
\hline Barrie & 17.3 & 94.6 & 105.3 & & & & 13.5 & 15.9 & 117.8 \\
\hline Brantford & 17.3 & 101.2 & 108.5 & & & & 11.4 & 9.9 & 86.8 \\
\hline Kingston & 15.6 & 107.4 & 111.1 & 22.3 & 20.0 & 89.7 & 12.7 & 11.6 & 91.3 \\
\hline Thunder Bay & 14.2 & 99.1 & 112.1 & 20.3 & 19.0 & 93.6 & 10.9 & 9.7 & 89.0 \\
\hline Peterborough & 12.4 & 93.9 & 108.8 & & & & 14.0 & 12.7 & 90.7 \\
\hline $\begin{array}{l}\text { Greater } \\
\text { Sudbury }\end{array}$ & 9.6 & 108.6 & 115.1 & 21.3 & 19.6 & 92.0 & 10.0 & 6.4 & 64.0 \\
\hline Saskatoon & 9.1 & 110.6 & 108.4 & 22.3 & 22.1 & 99.1 & 9.3 & 8.8 & 94.6 \\
\hline Regina & 9.0 & 108.7 & 100.6 & 20.5 & 19.3 & 94.1 & 9.6 & 8.4 & 87.5 \\
\hline Halifax & 8.3 & 110.7 & 106.6 & 22.0 & 21.5 & 97.7 & 13.6 & 15.5 & 114.0 \\
\hline Sherbrooke & 5.2 & 94.3 & 78.3 & 21.7 & 23.4 & 107.8 & 9.5 & 16.9 & 177.9 \\
\hline $\begin{array}{l}\text { Saint John } \\
\text { (NB) }\end{array}$ & 5.1 & 111.8 & 109.4 & 19.6 & 17.4 & 88.8 & 9.6 & 8.9 & 92.7 \\
\hline Moncton & 3.9 & 102.9 & 106.4 & & & & 10.8 & 11.3 & 104.6 \\
\hline
\end{tabular}




\begin{tabular}{|l|l|l|l|l|l|l|l|l|l|}
\hline $\begin{array}{l}\text { St. John's } \\
\text { (NF) }\end{array}$ & 3.7 & 147.0 & 109.2 & 21.1 & 16.5 & 78.2 & 13.5 & 12.7 & 94.1 \\
\hline Québec & 3.5 & 94.1 & 83.8 & 20.8 & 21.9 & 105.3 & 9.3 & 14.9 & 160.2 \\
\hline Trois-Rivières & 2.0 & 93.8 & 87.5 & 20.7 & 19.3 & 93.2 & 12.3 & 18.7 & 152.0 \\
\hline Saguenay & 0.8 & 133.8 & 88.9 & 19.7 & 18.8 & 95.4 & 8.2 & 6.7 & 81.7 \\
\hline Toronto & 54.8 & 87.3 & 101.0 & 23.5 & 24.6 & 104.7 & 19.0 & 23.4 & 123.2 \\
\hline Vancouver & 42.6 & 93.2 & 107.1 & 24.2 & 25.1 & 103.7 & 17.0 & 20.7 & 121.8 \\
\hline Montreal & 23.0 & 88.7 & 91.9 & 22.4 & 24.6 & 109.8 & 12.6 & 18.5 & 146.8 \\
\hline
\end{tabular}

Note: *Denotes data for 2001 only; 2006 data not available

Table 1: Household statistics by household immigrant status. Census Metropolitan Areas, 2006.

Adapted from CMHC, 2010; CMHC, 2004. Copyright 2010, 2004 by Canada Mortgage and

\section{Housing Corporation.}

\begin{tabular}{|c|c|c|c|c|c|c|c|c|c|}
\hline \multicolumn{10}{|c|}{ Household statistics by household immigrant status ( $<5$ yrs. in Canada). Census Metropolitan Areas, 2006} \\
\hline CMAs & 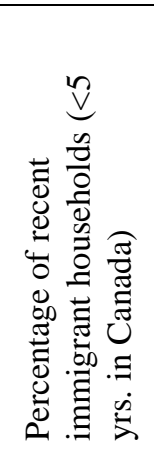 & 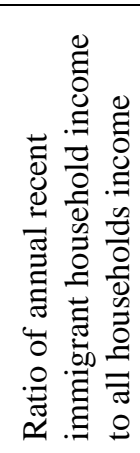 & 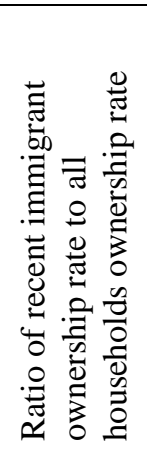 & 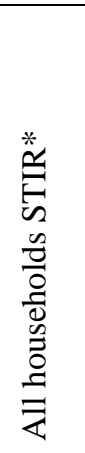 & 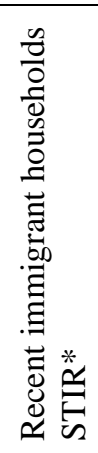 & 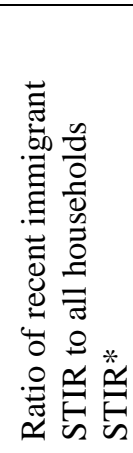 & 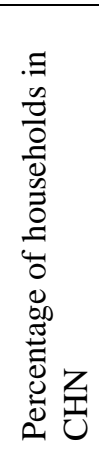 & 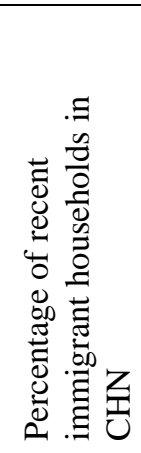 & 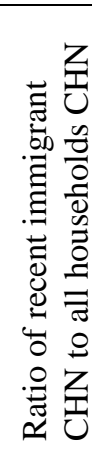 \\
\hline Hamilton & 2.0 & 65.0 & 45.1 & 21.9 & 29.1 & 132.9 & 12.9 & 34.9 & 270.5 \\
\hline Kitchener & 2.7 & 68.4 & 55.9 & 21.3 & 27.3 & 128.2 & 10.3 & 24.3 & 235.9 \\
\hline Abbotsford & 2.6 & 82.5 & 72.9 & 23.6 & 25.6 & 108.5 & 12.9 & 21.2 & 164.3 \\
\hline Windsor & 2.7 & 65.9 & 50.2 & 20.8 & 28.1 & 135.1 & 12.7 & 30.8 & 242.5 \\
\hline Calgary & 3.6 & 63.3 & 75.0 & 21.2 & 28.5 & 134.4 & 9.0 & 21.4 & 237.8 \\
\hline Guelph & 2.4 & 73.0 & 55.7 & & & & 11.8 & 23.9 & 202.5 \\
\hline $\begin{array}{l}\text { St. Catharines- } \\
\text { Niagara }\end{array}$ & 1.2 & 72.4 & 50.9 & 21.5 & 27.2 & 126.5 & 12.2 & 28.5 & 233.6 \\
\hline London & 1.8 & 66.9 & 46.9 & 22.4 & 33.3 & 148.7 & 12.8 & 34.0 & 265.6 \\
\hline Victoria & 1.0 & 80.7 & 66.0 & 23.1 & 29.6 & 128.1 & 12.4 & 24.5 & 197.6 \\
\hline Oshawa & 0.8 & 80.8 & 87.8 & 21.8 & 30.8 & 141.3 & 11.6 & 21.8 & 187.9 \\
\hline Edmonton & 2.1 & 67.9 & 57.4 & 20.7 & 27.6 & 133.3 & 10.6 & 26.7 & 251.9 \\
\hline Winnipeg & 2.1 & 69.5 & 52.4 & 20.4 & 25.5 & 125.0 & 10.4 & 23.3 & 224.0 \\
\hline $\begin{array}{l}\text { Ottawa- } \\
\text { Gatineau }\end{array}$ & 2.0 & 63.7 & 42.3 & 20.5 & 27.7 & 135.1 & 12.1 & 39.0 & 322.3 \\
\hline Kelowna & 0.9 & 77.4 & 71.5 & & & & 11.1 & 13.3 & 119.8 \\
\hline Barrie & 0.7 & 76.8 & 91.3 & & & & 13.5 & 37.2 & 275.6 \\
\hline
\end{tabular}




\begin{tabular}{|l|l|l|l|l|l|l|l|l|l|}
\hline Brantford & 0.6 & 87.2 & 65.8 & & & & 11.4 & 11.1 & 97.4 \\
\hline Kingston & 1.0 & 78.5 & 49.9 & 22.3 & 29.2 & 130.9 & 12.7 & 25.7 & 202.4 \\
\hline Thunder Bay & 0.3 & 75.0 & 48.1 & 20.3 & 23.7 & 116.7 & 10.9 & 19.4 & 178.0 \\
\hline Peterborough & 0.4 & 84.3 & 53.0 & & & & 14.0 & 30.0 & 214.3 \\
\hline $\begin{array}{l}\text { Greater } \\
\text { Sudbury }\end{array}$ & 0.3 & 92.0 & 74.7 & 21.3 & 23.7 & 111.3 & 10.0 & n.a. & \\
\hline Saskatoon & 0.9 & 72.2 & 59.4 & 22.3 & 30.1 & 135.0 & 9.3 & 24.3 & 261.3 \\
\hline Regina & 0.7 & 124.8 & 40.0 & 20.5 & 29.6 & 144.4 & 9.6 & 24.8 & 258.3 \\
\hline Halifax & 0.8 & 75.6 & 52.0 & 22.0 & 31.5 & 143.2 & 13.6 & 29.2 & 214.7 \\
\hline Sherbrooke & 1.3 & 62.6 & 25.2 & 21.7 & 31.7 & 146.1 & 9.5 & 35.0 & 368.4 \\
\hline $\begin{array}{l}\text { Saint John } \\
\text { (NB) }\end{array}$ & 0.3 & 103.6 & 56.6 & 19.6 & 29.7 & 151.5 & 9.6 & 33.3 & 346.9 \\
\hline Moncton & 0.4 & 80.2 & 53.0 & & & & 10.8 & 22.0 & 203.7 \\
\hline $\begin{array}{l}\text { St. John’s } \\
\text { (NF) }\end{array}$ & 0.3 & 95.0 & 74.5 & 21.1 & 24.6 & 116.6 & 13.5 & 20.4 & 151.1 \\
\hline Québec & 0.7 & 64.4 & 31.9 & 20.8 & 26.3 & 126.4 & 9.3 & 29.1 & 312.9 \\
\hline Trois-Rivières & 0.4 & 53.5 & 26.9 & 20.7 & n.a. & & 12.3 & 37.0 & 300.8 \\
\hline Saguenay & 0.2 & 88.7 & 35.7 & 19.7 & n.a. & & 8.2 & n.a. & \\
\hline Toronto & 6.0 & 59.0 & 55.2 & 23.5 & 32.7 & 139.1 & 19.0 & 42.5 & 223.7 \\
\hline Vancouver & 4.6 & 66.4 & 66.5 & 24.2 & 32.4 & 133.9 & 17.0 & 37.4 & 220.0 \\
\hline Montreal & 3.5 & 58.9 & 27.2 & 22.4 & 29.9 & 133.5 & 12.6 & 35.0 & 277.8 \\
\hline
\end{tabular}

Note: *Denotes data for 2001 only; 2006 data not available

Table 2: Household statistics by household immigrant status ( $<5$ yrs. in Canada). Census

Metropolitan Areas, 2006. Adapted from CMHC, 2010; CMHC, 2004. Copyright 2010, 2004 by

Canada Mortgage and Housing Corporation.

Immigrant household income is presented in the third column of Table 1 . The ratio of annual immigrant household income in relation to income of all households in a CMA denotes the parity level; $100 \%$ thus means that immigrant household income levels are equal to the average income level for the CMA. This examination demonstrates clearly that in terms of income immigrants fare better in second-tier cities than they do in the three largest metropolises. The only exceptions to this are the cities of Calgary and Kelowna, where immigrants earn only $88.1 \%$ and $87.4 \%$, respectively, of the city’s average income level. However, both Calgary and Kelowna still fare better than Toronto, where immigrants only achieve $87.3 \%$ of the city's average income levels. 
These results are in line with Bernard's (2008) findings which demonstrated, through a regression analysis, that even though immigrants generally earn less in second-tier cities compared to the largest cities the gap is not as pronounced in smaller centres. Likewise in Table 2, third column denotes the ratio of recent immigrant household (less than 5 years in Canada) income in relation to all other households. Table 2 similarly shows that, except in Trois-Rivières, recent immigrants' income is proportionately higher in second-tier cities than in the three largest although some Ontario CMAs-Hamilton (65.0\%), Windsor (65.9) and Ottawa-Gatineau (63.7\%) —as well as Calgary (63.3\%) perform worse than Vancouver (66.4\%) where recent immigrants have the highest income level among the big three. In some second-tier cities, such as Regina, recent immigrant households have almost $25 \%$ higher income than all other households in the city.

An examination of the immigrant household homeownership rate reveals somewhat mixed results. Immigrants in Quebec's CMAs, both second-tier cities and Montreal, have the lowest overall homeownership rate among all CMAs. This is in line with the lower overall homeownership rate in Quebec in comparison to all other provinces in Canada. The second-tier cities of Sherbrooke, Québec, Trois-Rivières, and Saguenay in Quebec, with 78.3\%, 83.8\%, 87.5\%, and 88.9\% ratios respectively, fare worse than Montreal (91.9\%) in terms of homeownership rate. However, most other second-tier cities (outside of Quebec) have better immigrant homeownership rates than Toronto, with the only exceptions being the CMAs of Windsor, Ottawa-Gatineau, and Regina. Vancouver's homeownership rate of $107.1 \%$ is slightly lower when compared to second-tier cities in B.C. with 107.4\% in Kelowna and 108.3\% in Abbotsford, with homeownership rate being higher in Victoria with 112.7\%. Victoria's homeownership rate is the highest among all 33 CMAs. With the exception of Quebec, these findings demonstrate that immigrants in second-tier cities are achieving more progress in their 
housing trajectories than in the largest cities. Since homeownership is considered a positive and progressive housing trajectory, as well as something that many immigrants aspire to achieve, it seems that immigrants, in this regard, are achieving more success in second-tier cities. What these results do not reveal, however, is whether immigrants are making strides in their housing trajectories due to overall economic uplift or are simply being pushed into homeownership due to a lack of affordable housing options, as in the case of York Region (Preston et al., 2009). The situation is somewhat different for recent immigrants (less than 5 years in Canada). As indicated in Table 2, in terms of homeownership rates recent immigrants do not perform as well in secondtier cities as they do in Toronto and Vancouver. Homeownership seems to be quite unattainable for new immigrants in Quebec, in comparison to the rest of the country, with only 27.2\% ownership rate in Montreal, 35.7\% in Saguenay, 31.9\% in Québec City, and even lower than Montreal in Trois-Rivières 26.9\% and Sherbrooke 25.2\%. Even more striking is the finding that new immigrants seem to fare better in Toronto, in terms of homeownership rate, than in most of Ontario’s CMAs. The only exceptions to this in Ontario are Barrie and Oshawa with substantially higher new immigrant homeownership rates (91.3\% and 87.8\% respectively). Moreover, in second-tier cities of Regina, Halifax and Moncton, and most second-tier cities in Ontario recent immigrants display lower rates than immigrants who have been in Canada for more than five years as new immigrant homeownership rate is half as much as it is for more established immigrants.

An examination of STIR compares the affordability of housing between the second-tier and the three largest cities. Table 1 denotes the following three categories of STIR: all households' average STIR, immigrant households' average STIR, and the ratio between these two. Thus, 100\% indicates that immigrant households are paying the same amount for shelter expenditures as households in a CMA. What the numbers reveal is the fact that less popular 
immigrant destinations, such as St. John's, Saint John, Saguenay, Greater Sudbury, and Thunder Bay are the most affordable despite having lower unemployment rates (in some cases 2\% lower)—-therefore being potentially more attractive for immigrant settlement—-than the big three (Statistics Canada, 2012b). More importantly, with the exception of Québec City and Sherbrooke in Quebec, and Ottawa-Gatineau in Ontario, second-tier cities across Canada are more affordable than the three largest cities. Additionally, adequacy and suitability issues are more pronounced in the largest three metropolises than in the second-tier cities (CMHC, 2010). However, this is not the case for recent immigrants (less than 5 years in Canada) as Table 2 denotes somewhat mixed results in terms of affordability of second-tier cities; London, Oshawa, Regina, Halifax, Sherbrooke, and Saint John are all less affordable than the three largest cities while Windsor, Calgary, Ottawa-Gatineau, and Saskatoon are less affordable than either Vancouver or Montreal. This finding may be important not only from the immigrant dispersion policy perspective but also from the integration perspective, because for immigrants affordability presents the biggest barrier in housing access (Wayland, 2007; Murdie, 2003).

The issue of core housing need reveals the extent of the housing problem for the most economically disadvantaged immigrants. As Table 1 demonstrates, core housing need for immigrants in second-tier cities, for the most part, is less severe than in the three largest cities, however, as per Table 2, this is not entirely the case for recent immigrants who have been in Canada for less than 5 years. The immigrant core housing situation in some Quebec municipalities, such as Trois-Rivières, Québec City, and Sherbrooke appears to be bleak. The ratio of immigrant core housing need (152.0\%, 160.2\%, and $177.9 \%$ respectively) relative to all household core housing need in these cities reveals that immigrant households are much more likely to be in this situation than other households, and additionally much more so than in the three largest cities. The extent of the problem is further demonstrated by the fact that immigrants 
in Quebec fare better in Montreal than in second-tier cities; however, Montreal fares the worst in terms of the immigrant core housing need among the three largest cities. What is also unfortunate is the fact that the two second-tier cities which attract a fair number of immigrants, Calgary and Ottawa-Gatineau, have a more extensive problem of immigrant core housing need than the largest cities. Ottawa-Gatineau's extent of the problem, in terms of numbers at least, is surprisingly similar to the second-tier cities in Quebec, and is worse than Montreal's. For new immigrants, the core housing need in less pronounced in British Columbia where they fare better in second-tier cities than they do in Vancouver. However, this is not the case in the rest of the country; in most CMAs in Ontario more new immigrants experience core housing need than in Toronto, as is the case in other CMAs across the country, such as Calgary, Edmonton, Winnipeg, Saskatoon, Regina and Saint John. Similarly in Quebec, new immigrants are more likely to be in core housing need in second-tier cities than in Montreal. The numbers additionally reveal that even though, overall, immigrants in second-tier cities fare better in terms of core housing need than in the largest cities, they still fare worse than other households in corresponding cities, especially when these cities tend to be attractive to immigrants. This further underscores the extent of the affordability problem, which additionally burdens most economically disadvantaged immigrants and hampers their integration process. Not only is the income polarity between immigrant haves and have-nots obvious, as Hulchanski (2007) has demonstrated, but this is increasingly being magnified, at least for the most disadvantaged, by housing access polarity between immigrants on one side and all others on the other.

Lastly, Table 3 presents rental market indicators for apartment structures with three or more units in all 33 CMAs across Canada. According to CMHC (2012), vacancy rate indicates units that are physically unoccupied and are immediately available. On the other hand, "available" denotes a unit which is either unoccupied or the existing tenant has given or received 
a notice to move. As available units encompass the vacant units the rate for available units is thus always higher. Table 3 reveals that, in October 2012, second-tier cities of Regina, Thunder Bay, and Calgary had the lowest vacancy rates in the apartment rental market with $1.0 \%, 1.1 \%$, and $1.3 \%$ rates respectively. The cities with the highest vacancy rates were in Saint John (9.7\%), Windsor (7.3\%) and Moncton (6.7\%) (CMHC, 2012). Overall, second-tier cities had higher vacancy rates, in 2012, when compared to Toronto and Vancouver (1.7\% and 1.8\% respectively), except in Calgary (1.3\%), Guelph (1.4\%), Thunder Bay (1.1\%), and Regina (1.0\%). Regina additionally had the lowest vacancy rate in the country. In terms of availability of rental units, Edmonton and Winnipeg had fewer units available in the rental market than either Toronto or Vancouver. In Quebec, only Saguenay and Québec City had lower vacancy and availability rates than Montreal although their vacancy rates were still higher than in either Toronto or Vancouver. As expected, average rents for two bedroom apartments were the highest in Toronto $(\$ 1,183)$ and Vancouver (\$1,261), thus being costlier than all other second-tier cities. In Quebec, apartment rental in Québec City (\$741) was slightly more expensive than in Montreal (\$711), although Quebec's CMAs are the most affordable in Canada in terms of apartment rental cost. The last column of Table 3 reveals that average rents for about a half of second-tier cities are getting higher and increasing proportionately more than in the three largest cities. The largest average rental price increase in 2012 occurred in Calgary with 5.9\% change during the preceding year. These rental market indicators reveal that low vacancy rates and highest apartment rental costs correspond to the largest number of immigrants settling in in the three largest cities, albeit with distinct differences between Quebec and the rest of Canada. Moreover, the numbers reveal the connection between the availability of rental units and rental price increase as demonstrated in second-tier cities of Calgary, Guelph, Edmonton, Winnipeg, Thunder Bay, and Regina which subsequently impacts the affordability of rental units. In these cities, low vacancy and 
availability rates resulted in corresponding largest rental price increases: Calgary (2.6\% availability rate- $5.9 \%$ rent increase), Guelph ( $2.7 \%$ availability rate $-3.3 \%$ rent increase), Edmonton (2.3\% availability rate-3.8\% rent increase), Winnipeg (2.5\% availability rate-3.6\% rent increase), Thunder Bay (2.0\% availability rate $-5.4 \%$ rent increase), and Regina (1.6\% availability rate— $4.8 \%$ rent increase). Given that second-tier cities, in the light of the immigrant dispersal drive, rely on immigrants for demographic and economic growth, the connection between immigrant attraction, housing and affordability—rental accommodation being a part of it—must be clearly made as one of the drawing factors into smaller centres.

\begin{tabular}{|c|c|c|c|c|c|c|c|c|}
\hline \multicolumn{9}{|c|}{$\begin{array}{c}\text { Rental Market Indicators } \\
\text { Privately Initiated Apartment Structures of Three Units and Over } \\
\text { Provinces and Major Centres }\end{array}$} \\
\hline & \multicolumn{2}{|c|}{$\begin{array}{l}\text { Vacancy } \\
\text { Rates (\%)(2) }\end{array}$} & \multicolumn{2}{|c|}{$\begin{array}{l}\text { Availability } \\
\text { Rates (\%) }\end{array}$} & \multicolumn{2}{|c|}{$\begin{array}{l}\text { Average Rent } \\
\text { 2-Bedroom } \\
\text { (\$) (New and } \\
\text { existing } \\
\text { structures) }\end{array}$} & \multicolumn{2}{|c|}{$\begin{array}{l}\text { Percentage Change } \\
\text { of Average Rent 2- } \\
\text { Bedroom From } \\
\text { Fixed Sample } \\
\text { (Existing structures } \\
\text { only) }\end{array}$} \\
\hline CMAs & $\begin{array}{l}\text { Oct. } \\
11\end{array}$ & $\begin{array}{l}\text { Oct. } \\
12\end{array}$ & $\begin{array}{l}\text { Oct. } \\
11\end{array}$ & $\begin{array}{l}\text { Oct. } \\
12\end{array}$ & $\begin{array}{l}\text { Oct. } \\
11\end{array}$ & $\begin{array}{l}\text { Oct. } \\
12\end{array}$ & $\begin{array}{l}\text { Oct. } 10 \\
\text { to Oct. } \\
11\end{array}$ & $\begin{array}{l}\text { Oct. } 11 \\
\text { to Oct. } \\
12\end{array}$ \\
\hline Hamilton CMA & 3.4 & 3.5 & 6.2 & 6.7 & 884 & 886 & 1.5 & 3.1 \\
\hline Kitchener CMA & 1.7 & 2.6 & 3.4 & 4.3 & 889 & 908 & 1.5 & 3.1 \\
\hline Abbotsford CMA & 6.7 & 4.2 & 7.5 & 5.4 & 800 & 818 & 2.6 & 1.2 \\
\hline Windsor CMA & 8.1 & 7.3 & 9.2 & 8.4 & 753 & 778 & 0.4 & 1.7 \\
\hline Calgary CMA & 1.9 & 1.3 & 3.2 & 2.6 & 1,084 & 1,150 & 1.9 & 5.9 \\
\hline Guelph CMA & 1.1 & 1.4 & 2.1 & 2.7 & 903 & 941 & 0.9 & 3.3 \\
\hline St. Catharines-Niagara CMA & 3.2 & 4.0 & 5.3 & 5.9 & 833 & 862 & 1.5 & 2.6 \\
\hline London CMA & 3.8 & 3.9 & 5.8 & 6.1 & 881 & 919 & 0.8 & 2.4 \\
\hline Victoria CMA & 2.1 & 2.7 & 3.3 & 3.7 & 1,045 & 1,059 & 2.4 & 0.9 \\
\hline Oshawa CMA & 1.8 & 2.1 & 3.2 & 3.4 & 941 & 939 & 2.0 & 1.5 \\
\hline Edmonton CMA & 3.3 & 1.7 & 4.3 & 2.3 & 1,034 & 1,071 & 0.9 & 3.8 \\
\hline Winnipeg CMA & 1.1 & 1.7 & 1.6 & 2.5 & 875 & 911 & 4.2 & 3.6 \\
\hline Ottawa-Gatineau CMA & 1.4 & 2.5 & 3.2 & 4.6 & 1,086 & 1,115 & 2.3 & 2.0 \\
\hline
\end{tabular}




\begin{tabular}{|l|l|l|l|l|l|l|l|l|}
\hline Kelowna CMA & 3.0 & 4.0 & 4.0 & 4.5 & 922 & 927 & -0.5 & \\
\hline Barrie CMA & 1.7 & 2.0 & 3.4 & 4.3 & 1,001 & 1,037 & 3.0 & 1.6 \\
\hline Brantford CMA & 1.8 & 3.5 & 3.1 & 5.2 & 792 & 838 & & 2.7 \\
\hline Kingston CMA & 1.1 & 1.7 & 2.2 & 2.9 & 965 & 1,005 & 1.6 & 3.1 \\
\hline Thunder Bay CMA & 1.7 & 1.1 & 2.9 & 2.0 & 772 & 818 & 2.9 & 5.4 \\
\hline Peterborough CMA & 3.5 & 2.7 & 4.8 & 4.8 & 899 & 904 & 2.0 & 1.6 \\
\hline Greater Sudbury CMA & 2.8 & 2.7 & 3.0 & 3.9 & 881 & 915 & 1.6 & 4.2 \\
\hline Saskatoon CMA & 2.6 & 2.6 & 4.0 & 3.8 & 966 & 1,002 & 2.8 & 2.4 \\
\hline Regina CMA & 0.6 & 1.0 & 0.9 & 1.6 & 932 & 979 & 6.2 & 4.8 \\
\hline Halifax CMA & 2.4 & 3.0 & 3.1 & 3.9 & 925 & 954 & 1.7 & 2.7 \\
\hline Sherbrooke CMA & 4.7 & 5.0 & 4.9 & 5.2 & 577 & 578 & 1.5 & 0.8 \\
\hline Saint John CMA & 5.9 & 9.7 & 6.7 & 10.1 & 670 & 691 & 3.1 & 3.4 \\
\hline Moncton CMA & 4.3 & 6.7 & 4.9 & 7.6 & 715 & 731 & 1.8 & 1.9 \\
\hline St. John's CMA & 1.3 & 2.8 & 1.8 & 3.3 & 771 & 798 & 5.4 & 4.0 \\
\hline Québec CMA & 1.6 & 2.0 & 1.8 & 2.3 & 718 & 741 & 3.0 & 2.3 \\
\hline Trois-Rivières CMA & 3.9 & 5.2 & 4.1 & 5.4 & 547 & 550 & 2.8 & \\
\hline Saguenay CMA & 1.4 & 2.0 & 1.7 & 2.4 & 557 & 549 & 3.5 & \\
\hline Toronto CMA & 1.4 & 1.7 & 2.9 & 3.0 & 1,149 & 1,183 & 1.9 & 2.8 \\
\hline Vancouver CMA & 1.4 & 1.8 & 2.1 & 2.7 & 1,237 & 1,261 & 2.4 & 2.3 \\
\hline Montreal CMA & 2.5 & 2.8 & 3.0 & 3.4 & 719 & 711 & 2.5 & 0.8 \\
\hline
\end{tabular}

Table 3: Rental Market Indicators: Privately Initiated Apartment Structures of Three Units and

Over. Provinces and Major Centres. Reprinted from CMHC, 2012. Copyright 2012 by Canada Mortgage and Housing Corporation. 


\section{Policy Overview}

This section examines policies and programs pertaining to housing, settlement, and immigrant dispersal and their effects on second-tier cities in Canada. Constraints and opportunities pertaining to housing and immigrant settlement in second-tier cities is examined in order to contribute to the discussion on housing and immigration policies. The three main government policy directions affecting immigrants in second-tier cities-immigration, settlement, and housing — have been identified and are presented next. The aim of this section is to identify confluences or contradictions among these policies and programs as they critically shape the process of immigrant integration.

\section{a) Immigration}

Canada is increasingly being shaped by immigration. The country is progressively being driven by immigration not only for economic growth (George, 2003) but also for population growth, accounting for two-thirds of Canadian population growth in 2006 (Statistics Canada, 2008). Immigration policy has played a decisive role in this outcome and has been, over the years, unfolding on a multitude of fronts from discourse, guidelines, and regulations to the actual government actions spurred by legislations (Green \& Green, 2004).

A closer examination of historical development on the immigration policy front reveals its connection to settlement policy. Historical settlement patterns have been structured and have occurred within specific geographic contexts. Several authors note that rural and unpopulated areas in the west and the prairies in the late nineteenth and early twentieth centuries were beneficiaries of a concentrated effort on the part of the government to populate these areas by settling large numbers of immigrants (Green \& Green, 2004; DiBiase \& Bauder, 2004). The main concern of the immigration and settlement policies was attracting immigrant workers to 
work and occupy agricultural land and to fill gaps in the industrial sector. This endeavor was arranged in tandem with the industrial sector, private agencies, and railroad authorities (Knowles, 2007; George, 2003).

Post WWII economic expansion resulted in the need for new skilled labour and immigration policy reorientation. This was spurred by the shortage of skilled industrial labourers as much as a desire to accelerate the country's progress by turning it into a manufacturing powerhouse (Knowles, 2007). As a result, a new immigration department was formed and tasked with overseeing the process of immigrant selection. A new points system for immigrant selection was established in the late 1960s to determine the admissibility of applicants (Shi, 2004; Green \& Green, 1995). Subsequently, in the 1970s the points system was expanded to address the problem of worker shortages through the employment or temporary visa category with the aim to help employers satisfy their labour needs (Knowles, 2007).

The current immigration policy enshrined the long-standing points system of immigrant selection through the Immigration and Refugee Protection Act in 2001 (Statutes of Canada, 2001). The Act identifies several classes of immigrant admission, such as economic, family or refugee class, and makes provisions for temporary workers and foreign students at Canadian universities to obtain residency upon securing job offers.

Over the years, the profound shift in immigration policy—from the predominantly rural and agricultural to the industrial, increasingly shaped by economic need—and subsequent urbanization of the country has resulted in an ever increasing share of immigrants settling in the largest metropolises of Toronto, Vancouver, and Montreal. There are undoubtedly many factors that have contributed to this outcome, some of which can be attributed to what Simmons and Bourne (2003) call a fragmented history of the Canadian urban system which evolved under periods of dramatic economic, social, and physical restructuring. 
At present, both home and abroad, efforts are being made to disperse immigrants away from major receiving centres, to attract them instead to smaller urban centres (Anderson, 2003; Citizenship and Immigration Canada, 2001). Until recently, the programs to attract and retain immigrants in Canada have largely been confined to specific sectors, such as in the case of medical staff in rural areas of Nova Scotia, Manitoba, and British Columbia or physicians from English-speaking countries. In these cases, trained immigrants are provided with an incentive to locate in alternative areas by being offered easier access to their professions (Citizenship and Immigration Canada, 2001).

Provincial Nominee Programs, introduced in the late 1990s, are incentive-based immigration dispersion programs designed jointly by the federal government and the provinces. The programs, based on the points system, are designed to cater to each province's specific labour needs and shortages. This priority is essentially addressed by giving preference in the processing of applicants to immigrants who meet the required employment criteria. Immigrants who meet the stated requirements become provincial nominees through this pre-selection process, which then ensures an expedited approval through the subsequent federal process. Provincial nominees thus bypass the federal admission's process and are only evaluated through security, health, and criminal checks. The provincial admissions process serves as an incentive because the admissibility criteria are usually broader and more lenient than the federal admissibility criteria. The process can either be employee- or province-driven depending on the specific labour needs of each province (Carter, 2009).

Provincial Nominee Programs vary across Canada, as each province has specific regional economic development criteria and immigration and labour priorities which need to be addressed (Standing Committee on Citizenship and Immigration, 2003). In New Brunswick, for example, two immigrant classes exist: job offer applicants and business applicants; in Saskatchewan, on 
the other hand, there are seven immigrant classes: entrepreneurs, foreign students, health care professionals, long haul truck drivers, family members, skilled workers, and farmers (Garcea, 2006). The program is accompanied by the settlement programs administered either nationally through the CIC and delivered by local community organizations, or in the case of British Columbia and Manitoba the responsibility for the settlement service delivery has been devolved, through an agreement, to the provincial domain. The exception to this is the province of Quebec, which has jurisdiction in both immigrant selection and processing as well as settlement services. Overall national levels of immigration administered through this program have been very small accounting for only 9.1\% of arrivals in 2008. However, the same year Manitoba presented a very different picture with $71 \%$ of immigrant arrivals being nominated by the province. In the ten years prior to 2008, Manitoba's total intake of immigrants through the PNP accounted for half of all arrivals (Carter, 2009). The program was also relatively successful in other western provinces, with British Columbia's intake at 13.2\%, Alberta’s at 9.4\%, and Saskatchewan's at 9.1\%. In all other provinces, the total number of arrivals accepted under this program amounted to less than 5\% (Citizenship and Immigration Canada, 2008). Thus, as a tool for regionalization and dispersal, the program has been most successfully and extensively employed in Manitoba where it has produced a substantial increase in the number of immigrants settling in the province. Garcea (2006) attributes the differing success rates of various provinces to the perceived needs, costs, and benefits associated with the dispersal program. Whereas immigration has contributed substantially to the growth of several provinces, Manitoba’s has remained relatively weak; therefore, the opportunity to actively use a tool which could entice more arrivals to settle into the province was born out of the need to reinforce the demographic and economic development. The PNP in Manitoba has been successful not only in attracting immigrants but also in increasing their dispersal throughout the province. Carter, Morrish, and Amoyaw (2008) attribute 
this success to the provincial involvement in the selection process, community involvement in planning for settlement of immigrants, involvement of employers, and promotion of sponsorship opportunities. In addition, these authors point out that the increased retention rate of immigrants has also occurred under the program and its success is largely due to the availability and affordability of housing, community and family ties, availability of employment opportunities, settlement support, language training, and access to health, social, education, and recreation opportunities. Derwing and Krahn (2008) point out that community support is uniquely important in Manitoba’s PNP context as any group—ethno-cultural, town, or region—can sponsor a number of immigrants. Nationwide, the sponsorship requirement is limited to refugee sponsorship, but in the case of Manitoba this means employer and social services guarantees are sufficient.

In the international arena, there are two notable examples of immigration dispersal policies. The first is Australia, where the approach to dispersal has centered on the broadening of sponsorship rights. The right to sponsor other family members or relatives is contingent upon settlement in predetermined areas where government has identified population gaps. The other example is Sweden, where government has embraced a more local approach by enlisting municipalities to disperse refugees into smaller urban centres. The participating municipalities are provided with adequate funding in order to establish programs and services to accommodate refugees in smaller centres (Andersson, 2003).

\section{b) Settlement Policy}

Settlement policy in Canada is implemented by way of programs and services intended to assist new arrivals in integrating into the host society. In supporting the successful integration of newcomers, CIC funds and administers three settlement programs, namely the Immigrant 
Settlement and Adaptation Program (ISAP), the Host Program, and the Language Instruction for Newcomers to Canada (LINC) Program, as well as a resettlement program for refugees called the Resettlement Assistance Program (RAP) (Citizenship and Immigration Canada, 2005). The ISAP programs and services are delivered through public and non-profit service providers, collectively called immigrant serving agencies (ISA), and are federally funded by CIC. Two provinces, Manitoba and British Columbia, are responsible for provisioning their own settlement services, while Quebec has maintained jurisdiction in both its immigration and settlement services since 1991 (Garcea, 2006).

The range of services offered by ISAs varies across the country, but in general they cover the areas of counselling and orientation, translation and interpretation, referral to community resources, language instruction in official languages, and employment services (Wayland, 2007). Additionally, some ISAs specialize in assisting refugees. In terms of housing-related services, ISAs assist clients with referrals, filling out forms, and getting clients on the social housing waiting lists. According to the Immigrant Settlement and Adaptation Program (ISAP), which provides guidance for the ISAs under the auspices of CIC, ISAs lack a specific mandate to assist newcomers in housing-related needs. They do, though, provide some guidance, albeit not in a systematic fashion, in the form of orientation to various neighbourhoods, and offer a range of accommodation and tenants’ rights information. Some ISAs, such as Hamilton’s Settlement \& Integration Services Organization and the Francophone Community Health Centre, provide additional housing services like roommate matching services to help newcomers with the reduction of housing expenses (Wayland, 2007). In contrast, Quebec government lists housingrelated services, such as directing newcomers to resources, services and programs pertaining to housing, information sessions on housing, housing search support, and related front-line services. 
Moreover, these services are offered to almost all immigrants (with the exception of refugee claimants) and can be accessed during the first five years of settlement (Wayland, 2007).

In Montreal, a unique community organization called Regroupement des Organismes du Montreal Ethnique pour le Logement (ROMEL) has positioned itself to bridge the gap between settlement and housing services. Initiated in 1985 as a joint project of seven community groups, the organization aimed to offer expertise and to serve the community needs in all housing-related matters by gathering information and disseminating it to its founding partners (ROMEL, 2012). This initial organizational role was subsequently augmented by creating social housing opportunities for various cultural and immigrant communities, such as the multiethnic housing cooperatives, with more than 1100 social housing units built since the early 1990s. As a tool in expanding its own portfolio, ROMEL invests in the purchase and conversion of existing housing, including repairs or renovation. In recognition of ROMEL's broad scope and engagement, Quebec’s government solidified its status as a 'Technical Resources Group’, which has ensured continued funding over the years and dedication to serving cultural and immigrant communities. On the settlement front, ROMEL contributes through linking prospective tenants with its own electronic database on housing availabilities in Montreal, where organizations, individuals, and private providers can submit their apartment listings. This apartment database is also available for refugee claimants referred to ROMEL by the immigration department (ROMEL, 2012). Additionally, ROMEL disseminates information on housing and civic engagement in several languages, organizes anti-discrimination awareness campaigns, assists clients with Housing Board-related matters, organizes training sessions—apartment search, lease and insurance contracts, rights and obligations of social housing, real estate management in a multiethnic environment, programs related to private housing ownership—as well as helping clients with rent supplement applications (ROMEL, 2012). 
In Ontario, similar to the earlier mentioned Swedish dispersal model, 2005 Canada Ontario Immigration Agreement (COIA) paved the way for a greater municipal role in the dispersion of immigrant settlements (Biles, Burstein, \& Frideres, 2008; Bradford \& Andrew, 2010). The COIA agreement recognized the critical role that municipalities and community groups can play in immigrant attraction and retention. To this end, increased federal funding for settlement services, spurred by federal desire for better service provisioning, converged with a municipal interest to increase the number of immigrant settlers in order to counter the economic and demographic decline. COIA thus helped create a policy framework and better coordination by connecting federal funding, the government sector (provincial and municipal) and the local settlement sector.

To achieve COIA objectives, Local Immigration Partnerships (LIPs) were created as instruments in capacity building of local institutions through the community-driven strategic planning process (Burr, 2011; Bradford \& Andrew, 2010). LIPs enable substantial autonomy for local communities to decide on the path and the scope of their strategic planning. LIPs are essentially local organizations, federally funded, with broad community representations and tasked with developing actions plans and implementation strategies for attracting and retaining immigrants in their respective communities. This multi-level collaborative governance serves to provide innovative services and delivery mechanisms to improve immigrant attraction, retention and integration by fostering labour market access, social inclusion, welcoming communities, increased immigrant participation (social, economic, political, and civic), and better integration of services across multiple sectors. This bottom-up action planning provides substantial freedom for interested parties—whether municipal governments, employers, or community agencies— to come together so that broad-based alliances that support inclusive and responsive environments can be created. There are currently 45 LIPs in Ontario, of which 30 are outside of Toronto (Burr, 
2011). LIPs in Ontario are highly praised for their collaborative strategies in settlement services provisioning, as was confirmed recently by the Standing Committee on Citizenship and Immigration's report on Best Practices in Settlement Services (House of Commons, 2010). The report recommended that the CIC continue to support and expand LIPs in Ontario and explore the potential for pilot projects in other interested provinces. However, LIPs settlement services, just like ISAP's, lack an established connection to the housing-related needs of immigrants, and have only recently begun to address this. Nadeau et al. (2012) in their analysis of LIPs in Ontario note that housing pressures are increasingly becoming evident in communities across the province, and even more so in city cores. In order to remedy this, several public housing providers are increasingly offering housing information in multiple languages, traditionally the prerogative of the settlement sector, to overcome the barriers in housing access. Similarly, by creating bridges between landlords and immigrants, community organizations aim to increase the stock of affordable housing. In addition, it has become evident that immigrants need choices of adequate and affordable housing in proximity to services and employment. To this end, Nadeau et al. (2012) identified municipalities and civic institutions as critical providers of local housing information and service coordination.

Several LIPs have recognized discrimination as a barrier in immigrant attraction and retention. To this end, several second-tier municipalities in Ontario, such as Ottawa, Hamilton, Windsor, and Waterloo have joined UNESCO’s Coalition of Municipalities Against Racism and Discrimination (Nadeau et al., 2012). Member municipalities pledge to create measures and monitoring tools to assess the levels of discrimination, reduce discrimination by setting specific targets, and support measures that promote equality and accessibility in the areas of housing, services, and employment. 


\section{c) Housing Policy}

Canadian housing policy is profoundly influenced by governments' actions in the housing sector, which aim to secure the production of housing through overarching mechanisms, such as mortgage and landing practices, taxation, regulation of professional activities, and subsidies and incentives. Governmental involvement in housing additionally manifests itself through jurisdictional arrangement, such as which level of government decides on which housing issues, and through a re-distributional arrangement of social welfare, such as when deciding which segments of population should benefit from specific actions on housing (Hulchanski, 2003). To this end, government has crafted its policies with two distinct aims in mind — one being market-based incentives, which stimulate homeownership and market housing, and on the other side disinvestment from provisioning of affordable housing. Since the late 1970s/early 1980s, federal government has significantly cut new funding for affordable housing to less than $5 \%$ of the number of units that were provided annually in the preceding decades. These years marked a shift in policy orientation from primarily federal to increased provincial role in provisioning and funding of affordable housing, increased cities' role in provisioning of social housing through non-profit organizations, and homeownership subsidies to alleviate housing and interest costs. Due to mounting financial pressures at that time, the solution was found in the federal government's disinvestment from a number of social areas, including housing. As a result of this, the provinces have responded by either cutting funding for affordable housing or offloading the responsibility to municipalities (Carter, 2005; Hulchanski, 2003).

The process of federal disentanglement and increased provincial role in provisioning for affordable housing was completed in 1993 when the federal government essentially withdrew from funding new social housing and subsequently transferred this role to the provinces in 1996 (Hulchanski, 2003). As a result of federal government withdrawal, provinces, faced with similar 
financial problems as the federal government, responded in kind and significantly cut funding for social housing projects. For example, Ontario’s commitment dropped from 1.7 billion (1997) to 798 million (2007) while Alberta’s spending, between 1991 and 2007, was reduced from 382 million to 190 million (Shapcott, 2007). Moreover, Ontario further devolved its responsibility for social housing onto municipalities, under an initiative called Local Services Realignment, with the creation of the Social Housing Services Corporation in 2002 to provide housing-related services for municipal service managers and social housing providers across Ontario (Social Housing Services Corporation, 2011).

Instead of providing for social housing funding, since the mid-1990s federal programs have focused on providing support to specific groups, such as Home Adaptations for Seniors' Independence, the Shelter Enhancement Program for victims of family violence, and the Remote On-Reserve Housing Initiative, rather than providing housing assistance for low income households (Carter, 1997). Two programs funded by the federal government, the Residential Rehabilitation Assistance Program (RRAP) and Supporting Communities Partnership Initiative (SCPI) aim to increase the supply of affordable housing units through efforts directed at specific activities: RRAP provides financial assistance for conversions of abandoned and neglected buildings into housing and the creation of rental/rooming house residences in addition to helping low income and disabled persons make their homes adequate and accessible, while SCPI serves to increase the capacity of local community organizations and help them achieve their accommodation providing objectives through development of community plans that address the needs of homeless people (CMHC, 2013a; HRSDC, 2009).

In 1991, CMHC created the Canadian Centre for Public-Private Partnerships in Housing (CCPPPH) with the aim of fostering public/private cooperation in housing projects (CMHC, 2013b). The goal was to develop alternative delivery models of affordable housing rather than 
rely on government funding. In line with this, Moskalyk (2008) and Griffin (2004) found that social and affordable housing can be effectively delivered through the Public Private Partnerships (PPPs). Moskalyk’s (2008) research analyzed Regent Park in Toronto, the Bob Ward Residence in Calgary, and the Housing Opportunity Partnership in Winnipeg, and concluded that private organizations bring tremendous knowledge of the market mechanisms and development skill which can be utilized in building new social housing. Likewise, Toronto’s Let’s Build program has been successful due to contributions from a variety of partners, including the federal and provincial levels of government and community-based non-profit organizations of the private sector (Griffin, 2004). The key to the successful outcome of the aforementioned projects was the result of government having the right and prominent development parent, capable and comfortable in the leadership role, while carefully crafting expectations, roles, deliverables, and legal contracts within the partnership. The private sector additionally provided more flexibility and innovation in their approach to development, while at the same time it was better equipped to mitigate financial risks entailing development projects. Additionally, for Toronto's Let's Build, the sharing of costs among partners enabled the projects as no individual agency or organization had sufficient resources to create them on their own, while locating on lease-free city land, waiving of planning and development fees, and property tax reductions provided the additional impetus for the projects (Griffin, 2004).

In the early 2000s, it became evident, through the Prime Minister’s Caucus Task Force on Urban Issues, that neglect of urban issues, caused by rapid urbanization, resulted in diminished housing affordability, increased homelessness, traffic congestion, environmental degradation, infrastructural deterioration, and social problems (income polarization) (Hulchanksi, 2003). In response to this, cities, faced with limited resources and more people to serve, started to limit conversion or rental housing stock to market housing and providing some affordable housing 
through land use measures, such as bonus densities (Section 37 in Ontario) for developers in return for provision of affordable housing, mandatory inclusion of affordable units in new development—inclusionary zoning (in Vancouver), second units, and garden suites in existing residential neighbourhoods, and zoning infill sites for housing to deflect growth pressure. More recently, Bill 140 in 2011—the Strong Communities through Affordable Housing Act—brought about changes in Ontario which support increased municipal involvement through the requirement for housing and homelessness plans. Additionally, in an attempt to increase housing affordability, Bill 140 denotes housing as a matter of provincial interest, consolidates housing and homelessness programs, streamlines the reporting mechanism for municipalities and housing providers, simplifies rent-geared-to-income calculations, and provides a range of tools for municipalities to increase affordable housing supply such as second units and garden suites (Ministry of Municipal Affairs and Housing, 2010). It is too early to assess whether and when the changes introduced by Bill 140 will increase affordability and provide better housing access for all, including immigrants. Nevertheless, homelessness advocates have for years called for changes to zoning ordinances and the inclusion of second units and garden suites. While Bill 140 provides for second units and garden suites as one of the tools available to increase affordable housing supply, it remains to be seen whether indeed municipalities choose to enact the enabling zoning provisions.

\section{i) Housing for Immigrants}

Immigrants, upon arrival in Canada, rely mostly on finding housing in the private sector, due to the limited availability of housing in the social sector. As a result of policies that have favoured private market housing over a period of several decades, social housing stock has been reduced, due to deterioration or conversion to market housing, while only a modest number of new of social housing units was built since the late 1970s/early 1980s (Hulchanski, 2003; 
Klodawsky et al., 2005). At the same time, the number of new arrivals has steadily been rising, and this has significantly affected housing demand (Carter, 2005; Ley et al., 2001). As confirmed in Chapter IV, low vacancy rates and high apartment rental costs reflect the number of new immigrant settlers. This was demonstrated both in the case of the largest and second-tier cities. Given the fact that second-tier cities rely on immigration for demographic and economic growth, the lack of affordable housing (both public and private) presents a drawback to their attractiveness and potentially further compromises their economic development.

Immigrants in Canada face obstacles to integration due to issues with housing access, as demonstrated both in the largest as well as in second-tier cities. While it appears that immigrants are making great strides in second-tier cities in terms of income, homeownership rates, and reduced core housing need, in comparison to the three largest (as demonstrated in Chapter IV), this is not the case for new immigrants (less than 5 years in Canada). This disadvantage negatively impacts other issues that are also critical for integration, such as accessing social support networks, employment access, educational opportunities, health, and family life. Accessing housing provides immigrants with a base upon which they can build their lives by establishing home and community. This base is critical, as it represents a start in re-establishing one's own personal and cultural identity in a new environment—a first step in the resettlement process (Carter \& Polevychok, 2004; Danso \& Grant, 2000). As a result, second-tier cities must put more emphasis on accommodating new immigrants and providing for better housing access especially in the light of the need to make themselves more attractive to new settlers.

Additionally, when attempting to access housing, immigrants face discrimination, which is more prevalent in private market housing $(\mathrm{Li}, 2003)$. Social housing, although not immune to discriminatory practices, reduces the potential for discrimination through regulation and oversight which involves this sector. Conversely, adequate and timely access to social housing 
may aid the settlement process by reducing costs to other social policy areas, such as health, education, social assistance, and education (Carter \& Polevychok, 2004). This is critical, as immigrants are not only driving the housing growth but are expected to be the main driver of population and economic growth in the future.

Currently, there are no comprehensive national or provincial strategies aimed at helping immigrants find accommodation in social housing, which due to current government housing policies presents the only affordable option (Wayland, 2007). One notable exception is Ontario, where social housing provisioning for immigrants is encouraged through a recommended allocation of one in seven units for immigrants or refugees. In Toronto, Toronto Community Housing Corporation (TCHC) offers one in seven vacancies to the homeless immigrants (Housing Connections, 2013). However, in Toronto the number of homeless immigrants represents almost a third of all homeless people (CRICH, 2013), far exceeding the one in seven ratio. Another social housing provisioning measure exists for immigrants in Hamilton. This program for immigrants on waiting lists for social housing provides \$200 vouchers for alleviating rents in the private sector, which in turn makes rents comparable to the social assistance shelter allowance (Wayland, 2007). These modest examples of social housing allowances only scratch the surface of the actual need for affordable housing, which for immigrants presents the most serious barrier in accessing housing. 


\section{Discussion and Conclusion}

The beginning of this research on housing issues in second-tier cities demonstrated that discrimination, a lack of affordable housing, the importance of social networks in the housing search, and a more challenging situation for refugees are ubiquitous issues affecting immigrants in the largest metropolises. Despite this, literature research additionally found that second-tier cities are more attractive than the three major metropolises not only because of economic opportunities and the presence of family and friends but also because of quality of life factors, such as climate, city size, availability of services, lower cost of living, and also the perceived safety, attractiveness, and affordability of second-tier cities when compared to the big metropolises. However, the lack of timely, adequate, and relevant settlement and housing services appears to be an issue in second-tier cities, more so than in the three largest cities. The research confirms that provisioning in the areas of immigrant accommodation and integration, through welcoming communities, is critically important in smaller centres.

Welcoming communities encompass both spatial and discourse aspects, and both are necessary for immigrant success in smaller centres: The spatial aspect refers to an actual place which values immigrants and accommodates their needs, while the discourse aspect means having a local agency or community engaging in actions which facilitate integration (Esses et al., 2010). Thus, successful accommodation and integration of immigrants rests on a collective community effort which can create and support processes to effectively affect the outcomes for immigrants, as in the cases of Manitoba's PNP and LIPs in Ontario. In their analysis of what makes a welcoming community Esses et al. (2010) identified and ranked 17 characteristics and features necessary to facilitate the integration of immigrants. These included the presence of employment opportunities, fostering of social capital, and thirdly affordable and suitable housing. According to Esses et al. (2010), social capital refers to the immigrant's ability to form 
connections both within their own ethno-cultural group as well as more broadly with the rest of mainstream society, and both are instrumental as coping and integration mechanisms. Reliance on social networks is, moreover, emblematic of immigrants in the initial stages of the integration process, confirmed through research in both the largest and second-tier cities, as they rely on ethnic sources to inform the housing search more so than on the established agencies. However, smaller communities lack a critical mass of ethnic population, which the three largest cities offer in abundance, confirming this as one of the drawbacks of Manitoba's PNP drive.

Notwithstanding these findings, Robinson and Coleman (2000), and Derwing and Mulder (2003) found that the strategy of clustering immigrants to ensure the presence of ethnic compatriots, through settling them together in the same city, has ensured successful retention in smaller centres despite the lack of established corresponding ethnic groups in these cities. These findings underscore the importance of social capital and offer a potential solution for overcoming the barrier to immigrant attraction in smaller centres lacking the critical mass of ethno-cultural community members. Thus, a targeted immigration approach can successfully bridge the social capital deficiency of an individual community, which thus opens up new opportunities for the dispersion drive.

Immigration has had a profound influence on both the population and economic growth of Canada. Throughout history, immigration policy has helped shape settlements in the country, while simultaneously changing them from predominately rural to highly urban. This profound shift has, over the years, resulted in the largest share of immigrants settling in the largest metropolises of Vancouver, Toronto, and Montreal while some smaller centres and regions have, as a result, languished economically and demographically. To offset this, the federal government’s dispersion initiative, facilitated through the Provincial Nominee Program (PNP), aimed to affect a more even distribution of immigrants across the country, as well as away from 
the three largest centres in the direction of medium and smaller centres. The PNP significantly increased the number of immigrant settlers in some provinces, such as Manitoba, while also being relatively successful in others—British Columbia, Alberta, and Saskatchewan. Manitoba's example demonstrated that increasing the number of new immigrant settlers is a necessary prerequisite, but it nevertheless needs to be accompanied by a comprehensive settlement approach encompassing the selection process, community involvement in planning for the settlement of immigrants, the involvement of employers, and broad sponsorship opportunities in the province. The broad sponsorship opportunities in Manitoba echo Australia's example where the dispersal initiative is based on family sponsorship opportunities being contingent upon choosing to live in areas where there are government-identified population gaps.

Even though Manitoba's PNP was successful, some challenges, such as a lack of affordable housing and a lack of critical mass of ethnic compatriots, still remain, as immigrants are often willing to sacrifice economic success for living close to their ethnic community (Carter, Morrish, \& Amoyaw, 2008). In this regard, Ontario LIPs present an initiative similar to Manitoba's settlement program. As a multi-level collaborative governance tool LIPs serve to build the capacity of local institutions and service providers through strategic planning: By fostering labour market access, social inclusion, welcoming communities, immigrant participation, and coordination of services across multiple sectors, the goal is to better and faster integrate immigrants and attract them to smaller centres. Just like in Manitoba, Ontario’s LIPs are realizing that the missing link in providing for better access to housing is increasingly important for immigrant attraction; yet, other than increased coordination between settlement and housing sectors, it is beyond the financial reach of municipalities.

As a result of policies that have since the late 1970s/early 1980s favoured market provisioning for housing and disinvestment from the social housing across the country, the 
significant shortage of affordable housing is critically affecting the population at large, as well as immigrants for whom housing additionally represents a springboard into a new society. Since the mid-1990s, when the federal government withdrew from funding new social housing and transferred this role to the provinces, municipalities have assumed a new role of alleviating the housing crisis. Their role, due to limited financial leverage and a limited tax base, largely consisted of indirect measures aimed at affecting land use outcomes through limiting conversion of rental housing stock, bonus densities in return for affordable housing, inclusionary zoning, zoning for second units and garden suites, and infill housing. Although in many respects very powerful instruments that affect land use outcomes, land use tools have had limited success in increasing the supply of affordable housing, even in the largest centres such as Toronto and Vancouver. In Toronto, bonusing (Section 37) does not appear to be an effective tool in generating affordable housing, as it is a mechanism where benefits—affordable housing being only of many potential community benefits—are open to negotiation with a developer, and the decision whether or not to include housing as a benefit ultimately rests with a councillor (Mah, 2009). As the nature of the political process rests on appeasing the largest number of constituents, and not necessarily the ones who need affordable housing the most, the political pendulum thus tends to swing towards benefits which favour communities at large. In the case of Vancouver, inclusionary zoning has proven to be a very flexible tool yielding quick results; however, the withdrawal of funding by both the federal (1993) and provincial levels (2002) made its application a very limited attempt at reducing the housing affordability problem (Mah, 2009). Because these tools are not successfully tackling the problem in the largest cities—even though these cities have added economic and development clout, their positive effect in terms of reducing the housing affordability problem in second-tier cities remains questionable. 
Findings in second-tier cities demonstrated that, just like in the largest metropolises, discrimination is a ubiquitous problem affecting many immigrants and hampering their housing access and societal integration. This problem has been, over the years, magnified by the lack of investments, from all government levels, in the social housing sector, and the almost exclusive reliance on market mechanisms as a way to provide housing for all segments of society. Unfortunately, as Hulchanski (2003) noted, market housing incentives, administered by the federal and provincial governments, were geared to everyone but the population at the bottom of the economic ladder. As new members of Canadian society, immigrants experience the brunt of economic and social disadvantage. On the other hand, Hamilton’s example of assisting immigrants on social housing waiting lists, through vouchers for private rental, seems like a positive and proactive solution aimed at providing better accommodation for them. This example shows that even small steps, such as rent vouchers, can have a big impact on alleviating the affordability burden — the most serious problem in immigrant housing access—by bringing the private renal cost in line with the social assistance shelter allowance. This unique example could become a model to emulate in second-tier cities, in an effort to attract more immigrants by providing for better housing access, quicker integration, and ensuing contributions to society.

Likewise, ROMEL's example in Quebec demonstrates how to successfully bridge disjointed settlement and housing policies and better accommodate immigrants. By merging the delivery of multi-ethnic social housing units, linking tenants to providers (public and private) through its own database on housing availabilities, and widely disseminating housing information in several languages, ROMEL has managed to provide a comprehensive service while actively expanding the boundaries of both housing and settlement provisioning. Similar to PPPs, ROMEL is in a constant development of new services related to housing, such as the Land Trust Community, Loan Fund, and Working Cooperative in renovation construction, which aims 
to provide alternative funding and delivery mechanisms — despite their other activities being fully funded by the province of Quebec — with the ultimate goal of creating more social and affordable housing units. In line with this, Moskalyk (2008) concluded that while PPPs could be very useful in creating social housing, providers should nevertheless collaborate with all levels of government in order to secure a variety of supportive financial mechanisms, in addition to PPPs, that provide a revenue stream to stimulate the supply of affordable housing. To this end, two mechanisms, tax credits and community land trust funds implemented in the United States and the United Kingdom, could be replicated in the Canadian context (Moskalyk, 2008).

Given the fact that smaller centres depend on immigration for economic and demographic progress, and that accessing housing presents one of the pillars of broader integration into a society, addressing housing affordability in second-tier cities thus emanates as an issue requiring resolution as a way to attract and retain immigrants. The lack of adequate affordable housing capacity, after all, presented an obstacle in the otherwise successful Manitoba's PNP settlement drive and similar community capacity building and immigrant attracting initiative through LIPs in Ontario. Therefore, successful attraction and retention of immigrants in smaller centres, while boosting the demographic and economic capacity of a community and a city, also needs to divert from immigrant marketization and strive to authentically accommodate them. While it appears that immigrants in second-tier cities are for the most part performing better, albeit not the majority of new immigrants (less than 5 years in Canada) —in terms of income, core housing need, homeownership rate and affordability—increasing the number of new arrivals in smaller centres could be attempted through the effective bridging of the three main policy pillars that pertain to immigrant settlement (immigration, settlement services, and housing) which, at the moment, are profoundly disjointed. ROMEL's example shows how settlement and housing sectors can be successfully bridged, after all, while Manitoba's example demonstrates how to 
comprehensively merge immigration and settlement provisioning. To this end, broad sponsorship opportunities, addressing settlement needs (e.g. multi-sector collaboration LIPs, Manitoba’s example, local capacity building through welcoming communities), immigrant housing assistance (vouchers), dedicated units, zoning for secondary and garden suites, and alternative provisioning to increase affordable housing spectre (PPPs, Community Land Trusts) could all be used as tools for economic development to attract immigrants into smaller centres and comprehensively provide for their accommodation. After all, understanding and resolving the challenges immigrants face in their housing access and integration processes can help decision makers and planners resolve policy issues and create more welcoming cities and communities. While this research has attempted to summarize policy and housing access issues, and provide a range of options for second-tier cities in terms of how to better accommodate immigrants and increase the number of new arrivals, it lacks the in-depth analysis of individual second-tier cities and their specific issues. Moreover, when comparing the second-tier cities to the largest metropolises the knowledge gap, in terms of housing and settlement issues, became quite evident: In second-tier cities, the qualitative studies that exist focus on a particular ethnicity or immigration class, such as refugees. While undoubtedly providing invaluable information, these types of studies need to be accompanied by an overall analysis of the settlement needs, and housing and other barriers to comprehensively assess the challenges of each community, and provide for policy and planning measures to effectively attract and accommodate new arrivals. Moreover, longitudinal research in second-tier cities would be able to track immigrant housing trajectories and integration experiences over time. This research is necessary in order to better inform housing, settlement, and immigration policy recommendations at the national, provincial, and city levels, as all levels of government are keenly interested in the benefits provided by 
immigration. This further research would also help planners and policy makers create more responsive and welcoming communities for immigrants. 


\section{References}

Abu-Ayyash, C., \& Brochu, P. (2006). The uniqueness of the immigrant experience across Canada: A closer look at the Region of Waterloo. Our Diverse Cities, 2, 20-26.

Abu-Laban, B. (1999). The settlement experiences of refugees in Alberta. A study prepared for Citizenship and Immigration Canada. Calgary, Alb.: University of Alberta.

Access Alliance (2003). Best Practices for Working with Homeless Immigrants and Refugees. Toronto: Access Alliance Multicultural Community Health Centre. Retrieved from http://ceris.metropolis.net/Virtual\%20Library/housing_neighbourhoods/AccessAlliance/ Report.pdf

Andersson, R. (2003). Settlement dispersal of immigrants and refugees in Europe: Policy and outcomes. Research on immigration and integration in the metropolis. Vancouver Center of Excellence. Working Paper Series, no. 03-08. Retrieved from http://mbc.metropolis.net/assets/uploads/files/wp/2003/WP03-08.pdf

Anucha, U., Smylie, L., Mitchell, C., \& Omorodion, F. (2007). Exits and Returns: An Exploratory Longitudinal Study of Homeless People in Windsor-Essex County. Ottawa: Canada Mortgage and Housing Corporation. Retrieved from http://www.homelesshub.ca/\%28S\%28jxellq3fnhugzuycrb324f20\%29\%29/ResourceFiles /Exits_and_Returns_to_Homelessness_-_CMHC_Report.pdf

Balakrishnan, T. R. \& Wu, Z. (1992). Home Ownership Patterns and Ethnicity in Selected Canadian Cities. Canadian Journal of Sociology, 17, 389-403.

Bauder, H., Waters, J., \& Teo, S. Y. (2001). Impacts of Immigration on British Columbia: Population, Labour Markets, Housing Markets and International Linkages. Section 4. Working Paper No.99-19. Vancouver: Research on Immigration and Integration in the 
Metropolis. Retrieved from

http://www.mbc.metropolis.net/assets/uploads/files/wp/2001/WP01-17.pdf

Bernard, A. (2008). Immigrants in the Hinterlands. Statistics Canada. Retrieved from http://www.statcan.gc.ca/pub/75-001-x/2008101/article/10505-eng.htm

Bezanson, R. Z. (2003). Make Yourself at Home: Exploring Housing and Resettlement with Afghan Refugee Households in Kitchener-Waterloo, Ontario. Waterloo: Unpublished Master's Thesis, Department of Geography, University of Waterloo.

Biles, J., Burstein, M., \& Frideres, J. (2008). Immigration and Integration in Canada in the Twenty-first Century. Kingston, Ont.: School of Policy Studies, Queen's University.

Boucher, C. (2007). Social Housing in Ottawa. Our Diverse Cities, 3, 48-50.

Bradford, N. \& Andrew, C. (2010). Local Immigration Partnership Councils: A Promising Canadian Innovation. Welcoming Communities Initiative (WCI). Retrieved from http://welcomingcommunities.ca/library/report/local-immigration-partnership-councils-apromising-innovation/

Brochu, P. \& Abu-Ayyash, C. (2006). Barriers and Strategies for the Recruitment and Retention of Immigrants in London, Ontario. Our Diverse Cities, 2, 27-30.

Bryant, T. (2003). The Current State of Housing in Canada as a Social Determinant of Health. Policy Options, March 2003, 52-56.

Burr, K. (2011). Local Immigration Partnerships: Building Welcoming and Inclusive Communities through Multi-Level Governance. Horizons Policy Research Initiative. Retrieved from http://welcomingcommunities.ca/wp-content/uploads/2011/10/LocalImmigration-Partnerships-Building-Welcoming-and-Inclusive-Communities.pdf 
Canada, House of Commons (2010). Report of the Standing Committee on Citizenship and Immigration: Best Practices in Settlement Services. March 2010. Retrieved from http://olipplio.ca/sites/default/files/u11/2010\%20Standing\%20Committee\%20Report\%20\%20CIC.pdf

Carter, T. (2010). The Challenges of Increasing Diversity in Areas of Urban Decline: A Winnipeg Case Study. Canadian Issues/Thèmes Canadiens (Newcomer’s Experiences of Housing and Homelessness in Canada). Montréal: Association for Canadian Studies, Fall 2010, 96-99. Retrieved from http://canada.metropolis.net/publications/aec_citc_fall2010_e.pdf

Carter, T. (2009). An Evaluation of the Manitoba Provincial Nominee Program. Prepared for Manitoba Labour and Immigration. Retrieved from http://www.gov.mb.ca/immigration/pdf/pnp-manitoba-provincial-nominee-program-tomcarter-report-2009.pdf

Carter, T. (2005). The Influence of Immigration on Global City Housing Markets: The Canadian Perspective. Urban Policy and Research, 23(3), 265-286.

Carter, T. (1997). Current Practices for Procuring Affordable Housing: The Canadian Context. Housing Policy Debate, 8(3), 593-631.

Carter, T., Morrish, M., \& Amoyaw, B. (2008). Attracting immigrants to smaller urban and rural communities: Lessons learned from the Manitoba Provincial Nominee Program. Journal of International Migration and Integration, 9, 161-183. 
Carter, T., Pandey, M., \& Townsend, J. (2010). The Manitoba Provincial Nominee Program: Attraction, Integration and Retention of Immigrants. IRPP Study. Retrieved from http://www.irpp.org/pubs/IRPPstudy/IRPP_Study_no10.pdf

Carter, T \& Polevychok, C. (2004). Housing Is Good Social Policy. Research Report F50. Ottawa: Canadian Policy Research Networks. Retrieved from http://rcrpp.ca/documents/33525_en.pdf

CERA, Centre for Equality Rights in Accommodation (2009). Measuring Discrimination in Toronto’s Rental Housing Market. Retrieved from http://www.homelesshub.ca/Resource/Frame.aspx?url=http\%3a\%2f\%2fwww.equalityrig hts.org\%2fcera\%2fwpcontent\%2fuploads\%2f2010\%2f04\%2fCERAFinalReport.pdf\&id=49214\&title=Measuri ng+Discrimination+in+Toronto\%E2\%80\%99s+Rental+Housing+Market\&owner=121

Chambon, A., Hulchanski, D., Murdie, R., \& Texeira, C. (1997). Access to Housing in a Canadian City: Experiences of Three Immigrant Groups. Paper presented at the Urban Affairs Association Conference. Toronto. May 1997. Retrieved from http://ceris.metropolis.net/Virtual\%20Library/housing_neighbourhoods/chambon1.pdf

Chao, J. (1999). The Private Market Rental Housing Experience of Ghanaian Immigrant Households in Metropolitan Toronto: A Qualitative Analysis. Toronto: Unpublished Master’s Major Research Paper, Social Work, York University.

Chui, T., Tran, K., \& Maheux, H. (2007). Immigration in Canada: A portrait of the foreign-born population, 2006 Census. Catalogue no. 97-557-XIE. Ottawa: Statistics Canada. 
Citizenship and Immigration Canada (2008). Facts and Figures: Immigration Overview Permanent and Temporary Residents. Retrieved from http://www.cic.gc.ca/english/pdf/research-stats/facts2008.pdf

Citizenship and Immigration Canada. (2007). Immigration-an Overview. Retrieved from http://www.statcan.gc.ca/pub/71-606-x/2007001/4129571-eng.htm

Citizenship and Immigration Canada (2005). Evaluation of the Immigrant Settlement and Adaptation Program (ISAP). Retrieved from http://www.cic.gc.ca/english/resources/evaluation/isap/index.asp

Citizenship and Immigration Canada. (2001). Towards a More Balanced Geographic Distribution of Immigrants. Ottawa. Retrieved from http://www.cic.gc.ca/english/research/papers/geographic/geographic-toc.html

CMHC, Canada Mortgage and Housing Corporation (2013a). Rental Residential Rehabilitation Assistance Program — Rental RRAP. Retrieved from http://www.cmhcschl.gc.ca/en/co/prfinas/prfinas_008.cfm

CMHC, Canada Mortgage and Housing Corporation (2013b). History of CMHC. Retrieved from http://www.cmhc-schl.gc.ca/en/corp/about/hi/index.cfm

CMHC, Canada Mortgage and Housing Corporation (2012). Canada’s Rental Vacancy Rate Increases. Retrieved from http://www.cmhc-schl.gc.ca/en/corp/nero/nere/2012/2012-1213-0815.cfm

CMHC, Canada Mortgage and Housing Corporation (2010). 2006 Census Housing Series Issue: 7-The Housing Conditions of Immigrant Households. CMHC. Retrieved from 
https://www03.cmhc-

schl.gc.ca/catalog/productDetail.cfm?cat=164\&itm=35\&lang=en\&fr=1359596573578

CMHC, Canada Mortgage and Housing Corporation (2004). 2001 Census Housing Series: Issue 7 Revised—Immigrant Households. CMHC. Retrieved from https://www03.cmhcschl.gc.ca/catalog/productDetail.cfm?cat=43\&itm=92\&lang=en\&fr=1359596510478

CRICH (2013). Centre for Research on Inner City Health. St. Michael’s Hospital. Homelessness in Canadian Cities. Retrieved from http://www.stmichaelshospital.com/pdf/crich/homelessness-canadian-cities.pdf

Danso, R. \& Grant, M. (2000). Access to Housing as an Adaptive Strategy for Immigrant Groups: Africans in Calgary. Canadian Ethnic Studies, 32(3), 19-42.

Derwing, T. \& Krahn, H. (2008). Attracting and retaining immigrants outside the metropolis: is the pie too small for everyone to have a piece? Journal of International Migration and Integration, 9(2), 185 - 202.

Derwing, T. \& Krahn, H. (2006). Edmonton’s Approach to Attracting and Retaining Immigrants. Our Diverse Cities, 2, 9-13.

Derwing, T. \& Mulder, M. (2003). The Kosovar Sponsoring Experience in Northern Alberta. Journal of International Migration and Integration, 4, 217-237.

Di Biase, S. \& Bauder, H. (2005). Immigrant settlement in Ontario: Location and local labour markets. Canadian Ethnic Studies, 37(3), 114-135. 
Di Biase, S. \& Bauder, H. (2004). Immigrants in Ontario: Linking spatial settlement patterns and labour force characteristics. Retrieved from http://www.geography.ryerson.ca/hbauder/Immigrant\%20Labour/Settlement\%20in\%20O ntario_report.pdf

Dion, K. (2001). Immigrants' Perceptions of Housing Discrimination in Toronto: The Housing New Canadians Project. Journal of Social Issues, 57(3), 523-539.

Dumais, R. (2009). Immigrant settlement outside of the greater Toronto area: determinants of desirability. Theses and dissertations. Paper 567. Retrieved from http://digitalcommons.ryerson.ca/dissertations/567

Dunn, J. \& Dyck, I. (1998). Research on Immigration and Integration in the Metropolis. Vancouver Centre for Excellence. Retrieved from http://mbc.metropolis.net/assets/uploads/files/wp/1998/WP98-20.pdf

Esses, V., Hamilton, L., Bennett-AbuAyyash, C. \& Burstein, M. (2010). Characteristics of a Welcoming Community. Welcoming Communities Initiative. Citizenship and Immigration Canada. Retrieved from http://p2pcanada.ca/wpcontent/uploads/2011/09/Characteristics-of-a-Welcoming-Community-11.pdf

Farrell, M. (2005). Responding to Housing Instability among Newcomers. Canadian Issues, Spring: 119-122. Retrieved from http://canada.metropolis.net/pdfs/CITC_Spring_05_EN.pdf

Federation of Canadian Municipalities (2000). A National Affordable Housing Strategy. Retrieved from http://ginsler.com/sites/ginsler/files/strategy2-e.pdf 
Garcea, J. (2006). Provincial \& Territorial Immigrant Nominee Programs as Instruments for the Regionalization of Immigration in Canada: Overview and Assessment. International Metropolis Conference. Lisbon, Portugal. Retrieved from http://www.ceg.ul.pt/metropolis2006/WorkshopPresentations/Gulbenkian/JosephGarcea_ metropolis2006.pdf

George, U. (2003), Immigration and refugee policy in Canada: Past, present, and future. In A. Westhues (Ed), Canadian social policy: Issues and perspectives (3rd ed., p.145 -63). Canada: Wilfrid Laurier University Press.

Ghosh, S. (2007). Transnational Ties and Intra-immigrant Group Settlement Experiences: A Case Study of Indian Bengalis and Bangladeshis in Toronto. GeoJournal, 68(2-3), 223242.

Green, G. A., \& Green, D. (2004). The goals of Canada’s immigration policy: A historical perspective. Canadian Journal of Urban Research, 13(1), 102- 39.

Green, G. A., \& Green, D. (1995). Canadian immigration policy: The effectiveness of the point system and other instruments. The Canadian Journal of Economics, vol. 28, 4b (November), p. 1006-1041.

Griffin, L. (2004). Creating Affordable Housing in Toronto Using Public-Private Partnerships. Faculty of Environmental Studies. York University. Retrieved from http://yorkspace.library.yorku.ca/xmlui/handle/10315/18084

Gurnett, J. (2010). Finding a Place to Call Home: The Challenge of Housing Security for Immigrants in Alberta. Canadian Issues/Thèmes Canadiens (Newcomer’s Experiences of Housing and Homelessness in Canada). Montréal: Association for Canadian Studies, Fall 
2010, 100-103. Retrieved from

http://canada.metropolis.net/publications/aec_citc_fall2010_e.pdf

Haan, M. (2005). The decline of the immigrant home ownership advantage: Life-cycle, declining fortunes and changing housing careers in Montreal, Toronto and Vancouver, 1981-2001, Analytical Studies Branch, Research Paper Series, Ottawa: Statistics Canada. Retrieved from http://www5.statcan.gc.ca/bsolc/olc-cel/olccel?catno=11F0019MIE2005238\&lang=eng

Hiebert, D., Germain, A., Murdie, R., Preston, V., Renaud, J., Rose, D., Wyly, E., Ferreira, V., Mendez, P. \& Murnaghan, A.M. (2006). The Housing Situation and Needs of Recent Immigrants in the Montréal, Toronto, and Vancouver CMAs: an Overview. Ottawa: Canada Mortgage and Housing Corporation. Retrieved from http://canada.metropolis.net/pdfs/Research\%20report_65319.pdf

Hiebert, D., D’Addario, S., Sherrell, K., \& Chan, S. (2005). The Profile of Absolute and Relative Homelessness Among Immigrants, Refugees, and Refugee Claimants in the GVRD. Vancouver: MOSAIC. Retrieved from http://www.urbancentre.utoronto.ca/pdfs/elibrary/HLN-among-Immigrants-Vancou.pdf

Hulchanski, D. (2007). The Three Cities Within Toronto: Income Polarization among Toronto’s Neighbourhoods, 1970 — 2000. Cities Centre, University of Toronto. Retrieved from http://www.urbancentre.utoronto.ca/pdfs/curp/tnrn/Three-Cities-Within-Toronto-2010Final.pdf 
Hulchanski, D. (2005). Rethinking Canada’s Housing Affordability Challenge. Centre for Urban and Community Studies, University of Toronto. Retrieved from http://www.urbancentre.utoronto.ca/pdfs/elibrary/Hulchanski-Housing-Affd-pap.pdf Hulchanski, D. (2003). What Factors Shape Canadian Housing Policy? The Intergovernmental Role in Canada’s Housing System. In Canada, State of the Federation 2004: Municipal Federal - Provincial Relations, editors Robert Young and Christian Leuprecht. McGillQueen’s University Press, 2006, Chapter 10, pages 221-247. Retrieved from www.ppmppm.ca/SOTFS/Hulchanski.pdf

Hulchanski, D. (1995). The Concept of Housing Affordability: Six Contemporary Uses of the Housing Expenditure-to-Income Ratio. Housing Studies, 10(4), 471-492.

Hunter, P. (1999). A Homeless Prevention Strategy for Immigrants and Refugees. In Taking Responsibility for Homelessness: An Action Plan for Toronto, Background Papers, Volume I. Toronto: Report of the Mayor’s Homelessness Action Task Force. Retrieved from http://www.toronto.ca/pdf/homeless_action.pdf

Housing Connections (2013). Welcome to Housing Connections. Retrieved from http://www.housingconnections.ca/PDF/hcworkshop.pdf

HRSDC, Human Resources and Skills Development Canada (2009). Implementation Review: Supporting Communities Partnership Initiative (SCPI). Retrieved from http://www.hrsdc.gc.ca/eng/publications_resources/audit/2000/6572/page00.shtml

Hyndman, J., Schuurman, N., \& Fiedler, R. (2006). Size matters: Attracting new immigrants to Canadian cities. Journal of International Migration and Integration, 7(1), 1-25. 
Kilbride, K., Webber, S., Wong, C. \& Amaral, N. (2006). Plug Them in and Turn Them on: Homelessness, Immigrants, and Social Capital. Toronto: Report submitted to the Housing and Homelessness Branch of the Department of Human Resources and Social Development Canada. Retrieved from http://ceris.metropolis.net/Virtual Library/EResources/Kilbride2006.pdf

Klodawsky, F., T. Aubry, B. Behnia, C. Nicholson, and M. Young (2005). Findings and Conclusions from The Panel Study on Homelessness in Ottawa: Secondary Analysis of Responses of Study Participants Whose Country of Origin is Not Canada. Canadian Issues, Spring: 123-126. Retrieved from http://canada.metropolis.net/pdfs/CITC_Spring_05_EN.pdf

Knowles, V. (2007). Strangers at our gates : Canadian immigration and immigration policy, 1540-2006. Toronto: Dundurn.

Ley, D., Murphy, P., Olds, K., \& Randolph, B. (2001). Immigration and Housing in Gateway Cities: The Cases of Sydney and Vancouver. Working Paper No.01-03. Vancouver: Research on Immigration and Integration in the Metropolis. Retrieved from http://www.mbc.metropolis.net/assets/uploads/files/wp/2001/WP01-03.pdf

Ley, D. \& Smith, H. (2000). Relations between Deprivation and Immigrant Groups in Large Canadian Cities. Urban Studies, 37(1), 37-62.

Li, P. (2003). Destination Canada: Immigration debates and issues. Ontario: Oxford University press.

Lusis, T. \& Bauder, H. (2008). "Provincial" immigrants: the social, economic, and transnational experiences of the Filipino Canadian community in three Ontario second-tier cities. CERIS Working Paper No. 62. Retrieved from http://www.ceris.metropolis.net/wpcontent/uploads/pdf/research_publication/working_papers/wp62.pdf 
Mah, J. (2009). Can Inclusionary Zoning Help Address the Shortage of Affordable Housing in Toronto? CPRN Research Report. Canadian Policy Research Networks. Retrieved from http://www.cprn.ca/documents/51952_EN.pdf

Mattu, P. (2002). A Survey on the Extent of Substandard Housing Problems Faced by Immigrants and Refugees in the Lower Mainland of British Columbia. Research paper. Vancouver: MOSAIC. Retrieved from http://www.mosaicbc.com/sites/all/files/publicationspublic/SCPI\%20Summary\%20Report_0.pdf

Metropolis Project (2007). Symposium on Newcomers, Housing and Homelessness: Summary Report. Ottawa: Metropolis Project. Retrieved from http://canada.metropolis.net/pdfs/symp_newcmrs_housing_homelssness_e.pdf

Mikkonen, J., \& Raphael, D. (2010). Social Determinants of Health: The Canadian Facts. Toronto: York University School of Health Policy and Management. Retrieved from http://www.thecanadianfacts.org/The_Canadian_Facts.pdf

Ministry of Municipal Affairs and Housing (2010). Building Foundations: Building Futures. Ontario’s Long-Term Affordable Housing Strategy. Retrieved from http://www.mah.gov.on.ca/AssetFactory.aspx?did=8590

Miraftab, F. (2000). Sheltering Refugees: The Housing Experience of Refugees in Metropolitan Vancouver, Canada. Canadian Journal of Urban Research, 9(1), 42-60. 
Moskalyk, A. (2008). The Role of Public-Private Partnerships in Funding Social Housing in Canada. Canadian Policy Research Networks and Social Housing Services Corporation. Retrieved from http://www.cprn.org/documents/50550_EN.pdf

Murdie, R. (2010). Precarious Beginnings: The Housing Situation of Canada’s Refugees. Canadian Issues/Thèmes Canadiens (Newcomer's Experiences of Housing and Homelessness in Canada). Montréal: Association for Canadian Studies, Fall 2010: 47-51. Retrieved from http://canada.metropolis.net/publications/aec_citc_fall2010_e.pdf

Murdie, R.A. (2008). Diversity and Concentration in Canadian Immigration: Trends in Toronto, Montréal and Vancouver, 1971-2006. Toronto: Centre for Urban and Community Studies, Cities Centre, University of Toronto. Research Bulletin 42. Retrieved from http://www.urbancentre.utoronto.ca/redirects/rb42.html

Murdie, R. (2003). Housing Affordability and Toronto's Rental Market: Perspectives from the Careers of Jamaican, Polish and Somali Newcomers. Housing, Theory and Society, 20, 183-196.

Murdie, R. (2002). The Housing Careers of Polish and Somali Newcomers in Toronto's Rental Market. Housing Studies, 17(3), 423-443.

Murdie, R. \& Teixeira, C. (2004). Towards a comfortable neighbourhood and appropriate housing: Immigrant experiences in Toronto. CERIS Working Paper No. 10. Retrieved from http://ceris.metropolis.net/Virtual\%20Library/housing_neighbourhoods/murdie/murdietei xeira1.html 
Murdie, R., Chambon, A., Hulchanski, D. \& Teixeira, C. (1995). Housing Issues Facing Immigrants and Refugees in Greater Toronto: Initial Findings from the Jamaican, Polish and Somali Communities. Paper presented at Habitat II Research Conference. Ankara. November 23-25. Retrieved from www.library.utoronto.ca/hnc/publish/issues.pdf

Musterd, S. (2003). Segregation and Integration: a contested relationship. Journal of Ethnic and Migration Studies, 29(4), 623-641.

Nadeau, J., Satzewich, V., Rocheleau, J. \& Pour, K. (2012). Analysis of LIP Strategic Plans: Newcomer Attraction, Retention and Business Development. Welcoming Communities Initiative. Retrieved from http://welcomingcommunities.ca/wpcontent/uploads/2012/05/Analysis-of-LIP-Strategic-Plans_full-report.pdf

Novac, S., Darden, J. et al. (2002). Housing Discrimination in Canada: What do we Know About It? Toronto: University of Toronto, Centre for Urban and Community Studies Research Bulletin 11. Retrieved from http://www.urbancentre.utoronto.ca/pdfs/researchbulletins/11.pdf

Owusu, T. (1998). To Buy or Not to Buy: Determinants of Home Ownership Among Ghanaian Immigrants in Toronto. Canadian Geographer, 42(1), 40-52.

Propa, F. A. (2007). An Analytical Overview of the Factors Influencing Housing Accessibility of Bangladeshi Immigrants in Kitchener-Waterloo. Waterloo: Unpublished Master’s Thesis, Department of Geography, Wilfrid Laurier University. Retrieved from http://scholars.wlu.ca/cgi/viewcontent.cgi?article=1855\&context=etd 
Preston, V., Murdie, R., Wedlock, J., Kwak, M.J., D’Addario, S., Logan, J., Murnaghan, A.M., Agrawal, S., \& Anucha, U. (2009). At Risk in Canada’s Outer Suburbs: A Pilot Study of Immigrants and Homelessness in York Region. Chapter 5.3 in Hulchanski, J.D. et al., (editors). Finding Home: Policy Options for Addressing Homelessness in Canada. Toronto: Cities Centre, University of Toronto. Retrieved from http://www.homelesshub.ca/FindingHome

Ray, B. K. (1998). A Comparative Study of Immigrant Housing, Neighbourhoods and Social Networks in Toronto and Montréal. Ottawa: Canada Mortgage and Housing Corporation. Retrieved from http://publications.gc.ca/collections/collection_2011/schl-cmhc/nh18-12/NH18-1-2-101-1998-eng.pdf

Ray, B. K. \& Moore, E. (1991). Access to homeownership among immigrant groups in Canada. Canadian Review of Sociology and Anthropology, 28(1), 1-28.

Renaud, J., Gingras, L., Vachon, S., Blaser, C., Godin, J., \& Gagné, B. (2003). What a difference ten years can make! The settlement experience of immigrants admitted to Quebec in 1989. Les Publications du Québec.

Robinson, V. \& Coleman, C. (2000). Lessons Learned? A Critical Review of the Government Program to Resettle Bosnian Quota Refugees in the United Kingdom. International Migration Review, 34(4), 1212-1244.

ROMEL (2012). Regroupement des Organismes du Montreal Ethnique pour le Logement. Retrieved from http://romel-montreal.ca/index.php?lang=fr 
Rose, D. (2004). Immigrant Settlement Strategies and Support Needs in Canada’s Major Cities: Some Policy Issues. Conference Paper presented at What Makes Good Public Policy in Canadian Municipalities? Ottawa, Ontario. Retrieved from http://www.vrm.ca/documents/RoseMunicConf.pdf

Satzewich, V. \& Shaffir, W. (2007). Immigrants and Immigrant Settlement in Hamilton. Our Diverse Cities, 3, 118-122.

Schellenberg, G. (2004). Immigrants in Canada’s Census metropolitan areas. Catalogue no. 89613-MIE. Ottawa: Statistics Canada. Retrieved from http://publications.gc.ca/collections/Collection/Statcan/89-613-MIE/89-613MIE2004003.pdf

Sherrell, K. \& Immigrant Services Society of British Columbia (2009). At Home in Surrey? The Housing Experiences of Refugees in Surrey, B.C., Final Report. Surrey, B.C.: City of Surrey. Retrieved from http://issbc.org/publications

Shanes, M. (2006). Recent immigrants in Canada’s second-tier metropolitan areas: Highlights based on the 2001 Census. Our Diverse Cities, 2, 44-48.

Shapcott, M. (2007). National Housing Day 2007: Despite Promises, Few New Homes and Scarce Dollars. Policy Backgrounder prepared for the Wellesley Institute. Toronto. Retrieved from http://www.wellesleyinstitute.com/publication/national_housing_day_2007_despite_pro mises_few_new_homes_and_scarce_dollars/ 
Simmons, J. \& Bourne, L. (2003). The Canadian Urban System 1971-2001. Centre for Urban and Community Studies. University of Toronto. Retrieved from http://www.citiescentre.utoronto.ca/assets/cities\%2Bcentre\%2Bdigital\%2Bassets/pdfs/pu blications/research\%2Bpapers/200\%2Bsimmons\%2Bbourne\%2B2003\%2Bcanadian\%2B urban\%2Bsystem.pdf

Simon, P. (1998). Ghettos, immigrants, and integration the French dilemma. Housing and the Built Environment, 13, 41-61.

Skaburskis, A. (1996). Race and Tenure in Toronto. Urban Studies, 33(2), 223-52.

Social Housing Services Corporation (2011). About SHSC. Retrieved from http://www.shscorp.ca/content.aspx?file=SHSCCorporate/AboutSHSC.htm

Standing Committee on Citizenship and Immigration (2003). The Provincial Nominee Program: A Partnership to Attract Immigrants to All Parts of Canada. Joe Fontana, M.P. Chair. House of Commons. Ottawa. Retrieved from http://www.parl.gc.ca/HousePublications/Publication.aspx?DocId=1032307\&Language= E\&Mode $=1 \&$ Parl $=37 \&$ Ses $=2$

Statistics Canada (2012a). Census metropolitan area (CMA) and census agglomeration (CA). Statistics Canada. Retrieved from http://www12.statcan.gc.ca/censusrecensement/2011/ref/dict/geo009-eng.cfm

Statistics Canada (2012b). Labour force characteristics by census metropolitan area (seasonally adjusted) - 3 month moving average. Statistics Canada. Retrieved fromhttp://www.statcan.gc.ca/pub/71-001-x/2011007/t014-eng.htm 
Statistics Canada (2009). Shelter-cost-to-income-ratio (STIR) and the affordability standard.

Statistics Canada. Retrieved from http://www.statcan.gc.ca/pub/75f0002m/2008001/aBeng.htm

Statistics Canada (2008). Population growth in Canada. Statistics Canada. Retrieved fromhttp://www.statcan.gc.ca/pub/91-003-x/2007001/4129907-eng.htm

Stone, M. (1993). Shelter Poverty. Philadelphia, Pen.: Temple University Press.

Tanasescu, A., Classens, M., Turner, D., Richter-Salmons, S., Pruegger, V., \& Smart, A. (2009). Hidden in Plain Sight: Housing Challenges of Newcomers in Calgary. Calgary: Calgary Homeless Foundation and the United Way of Calgary and Area. Retrieved from http://www.homelesshub.net/sites/default/files/Hidden in Plain Sight FINAL.pdf

Teixeira, C. (2010). Housing Immigrants and Newcomers in Central Okanagan, BC. Vancouver: Metropolis British Columbia, Working Paper Series, No. 10-03. Retrieved from http://riim.metropolis.net/assets/uploads/files/wp/2010/WP10-03.pdf

Teixeira, C. (2009). New Immigrant Settlement in a Mid-Sized City: A Case Study of Housing Barriers and Coping Strategies in Kelowna, British Columbia. The Canadian Geographer, 53(3), 323-339.

Teixeira, C. (2007). Residential Experiences and the Culture of Suburbanization: A Case Study of Portuguese Homebuyers in Mississauga. Housing Studies, 22(4), 495-521. 
Teixeira, C. (2006). Housing Experiences of Black Africans in Toronto's Rental Market: A Case Study of Angolan and Mozambican Immigrants. Canadian Ethnic Studies, 38(3), 58-86. Wachsmuth, D. (2008). Housing for immigrants in Ontario’s medium-sized cities. Canadian Policy Research Networks. Retrieved from http://www.cprn.org/doc.cfm?doc=1937\&l=en

Walton-Roberts, M. (2011). Immigration, the University and the Welcoming Second-tier City. International Migration \& Integration, 12, 453-473.

Walton-Roberts, M. (2004). Regional Immigration and Dispersal: Lessons from Small-and Medium-sized Urban Centres in British Columbia. Research on Immigration and Integration in the Metropolis. Working Paper Series No. 04-03. Retrieved from http://www.mbc.metropolis.net/assets/uploads/files/wp/2004/WP04-03.pdf

Wayland, S. (2007). The Housing Needs of Immigrants and Refugees in Canada. Canadian Housing and Renewal Association (CHRA). Retrieved from http://path.relyonmedia.com/ResourceFiles/FinalReport_CHRAImmigrationHousing_Jun e_2007.pdf

Whitehead, S., Monk, S., Clarke, A., Holmans, A. \& Markkanen S. (2009). Measuring Housing Affordability: A Review of Data Sources. Cambridge Centre for Housing and Planning Research. Cambridge: University of Cambridge.

Wilson, A. M. (1992). Housing Needs and General Well-Being of Immigrants and Refugees in Calgary. Canada Mortgage and Housing Corporation. Retrieved from 
http://publications.gc.ca/collections/collection_2011/schl-cmhc/nh18-1-2/NH18-1-2-561992-eng.pdf

Zine, J. (2002). Living on the Ragged Edges: Absolute and Hidden Homelessness among Latin Americans and Muslims in West Central Toronto. Toronto: Informal Housing Network. Retrieved from http://nrchmi.samhsa.gov/ResourceFiles/Documents/5.1\%20Zine\%20\%20Latin\%20Americans\%20and\%20Muslims.pdf 